\title{
A Review on Micro- to Nanocellulose Biopolymer Scaffold Forming for Tissue Engineering Applications
}

H. P. S. Abdul Khalil ${ }^{1, * \mathbb{D}}$, Fauziah Jummaat ${ }^{2, *}$, Esam Bashir Yahya ${ }^{1, * \mathbb{D},}$ N. G. Olaiya ${ }^{1} \mathbb{D}$, A. S. Adnan ${ }^{2,3}$, Munifah Abdat ${ }^{4}$, Nasir N. A. M. ${ }^{(D)}$, Ahmad Sukari Halim ${ }^{5}$ (D), U. Seeta Uthaya Kumar ${ }^{1}$ (D), Rahul Bairwan ${ }^{6}$ and A. B. Suriani ${ }^{7}$

1 School of Industrial Technology, Universiti Sains Malaysia, Penang 11800, Malaysia; ngolaiya@futa.edu.ng (N.G.O.); seeta.uk@gmail.com (U.S.U.K.)

2 Management Science University Medical Centre, University Drive, Off Persiaran Olahraga, Section 13, Shah Alam 40100, Selangor, Malaysia; drazreenadnan@gmail.com

3 CKD Resource Centre, School of Medical Sciences, Health Campus, USM, Kubang Kerian 16150, Kelantan, Malaysia

4 Faculty of Medicine, Universitas Syiah Kuala, Banda Aceh 23311, Indonesia; munifahabdat_dr@unsyiah.ac.id

5 Reconstructive Sciences Unit, School of Medical Sciences, Health Campus USM, Kubang Kerian 16150, Kelantan, Malaysia; nurazida@usm.my (N.N.A.M.); ashalim@usm.my (A.S.H.)

6 Department of Aeronautical engineering, School of Aeronautics, Neemrana 301705, Rajasthan, India; rahulbairwan94@gmail.com

7 Nanotechnology Research Centre, Faculty of Science and Mathematics, UPSI, Tanjung Malim 35900, Perak, Malaysia; suriani@fsmt.upsi.edu.my

* Correspondence: akhalilhps@gmail.com (H.P.S.A.K.); drfauziahjummaat@gmail.com (F.J.); essam912013@gmail.com (E.B.Y.)

Received: 12 August 2020; Accepted: 5 September 2020; Published: 8 September 2020

\begin{abstract}
Biopolymers have been used as a replacement material for synthetic polymers in scaffold forming due to its biocompatibility and nontoxic properties. Production of scaffold for tissue repair is a major part of tissue engineering. Tissue engineering techniques for scaffold forming with cellulose-based material is at the forefront of present-day research. Micro- and nanocellulose-based materials are at the forefront of scientific development in the areas of biomedical engineering. Cellulose in scaffold forming has attracted a lot of attention because of its availability and toxicity properties. The discovery of nanocellulose has further improved the usability of cellulose as a reinforcement in biopolymers intended for scaffold fabrication. Its unique physical, chemical, mechanical, and biological properties offer some important advantages over synthetic polymer materials. This review presents a critical overview of micro- and nanoscale cellulose-based materials used for scaffold preparation. It also analyses the relationship between the method of fabrication and properties of the fabricated scaffold. The review concludes with future potential research on cellulose micro- and nano-based scaffolds. The review provides an up-to-date summary of the status and future prospective applications of micro- and nanocellulose-based scaffolds for tissue engineering.
\end{abstract}

Keywords: nanocellulose; tissue engineering; scaffold; biomedical; biocompatible

\section{Introduction}

Biopolymers are naturally sourced and have been reported to have good biocompatibility with the human system. Biopolymers have been proposed as a replacement for synthetic polymers used in tissue repair because of their nontoxic nature. Tissue engineering is an arm of regenerative medicine 
and for the most part makes use of scaffolds for the repair of tissues. Scaffold development with biopolymers for tissue repair has been at the forefront of material research, and cellulose, being the most abundant biopolymer, has been intensively investigated for this purpose.

Cellulose has been reported as the most abundant, naturally sourced biopolymer, with 150 billion tons produced yearly [1]. Plants mainly consist of cellulose, which provides them with their structural integrity. The use of naturally occurring polysaccharides for industrial applications has drawn the attention of many researchers. Natural polymers such as cellulose, starch, chitin, etc. have been used as the major materials for biomedical and packaging applications [2]. As a natural polymer, cellulose has been reported to be environmentally friendly, renewable, biodegradable, biocompatible, nontoxic, and covalently attach to many bioactive molecules [3]. As a result, it has been widely used in many medical and non-medical applications [4].

Microcellulose fibres have an area network of bundled microfibrils, which form slender and nearly endless rods. These microfibrils, when dissolved in strong acids, break down into short crystalline rods with a diameter range of 9-16 $\mu \mathrm{m}$, known as cellulose microcrystals $[5,6]$. Cellulose microfibrils are usually longer than microcrystals. Cellulose microfibrils range from a few hundred nanometres for wood or cotton cellulose to a few microns for cellulose from animal sources such as tunicates [7].

Nanocellulose has a larger surface area, and this is responsible for its good reinforcement ability [3]. Micro- and nanofibres in cellulose polymer are the structural unit and consist of multi-dozens of chains that lie against each other, forming one straight chain called a cellulose fibril. Most of the fibrils have cellulose chains in a precise 3D order. Thus, there are two main forms: crystalline and non-crystalline (amorphous) [8]. Several forms of cellulose have been used in the fabrication of biomedical scaffolds such as powders [9], hydrogels [10], aerogels [11], and membranes [12]. Cellulose materials have been majorly used in scaffold fabrication with poly-lactic acid (PLA), polybutylene succinate (PBS), chitosan, and starch. Scaffold materials have been researched with binary and ternary blends of nanocellulose with other polymers with good mechanical strength [13].

At present, several reviews have reported on the use of biopolymers in biomedical applications [14]. Athukoralalage et al. (2019) reviewed the properties of nano-cellulosic materials and their use in 3D bio-printed hydrogels. The review discussion was focused on previous work on hydrogel 3D printing technology. Another recent review reported on [15] bacteria cellulose-based scaffolds for biomedical applications. The major review discussion was centred on bacterial cellulose, which differs from plant-based cellulose, as discussed in this study. Furthermore, Hickey and Pelling [16] reported on the general overview of cellulose source, types, and application in tissue engineering without describing the technique of scaffold fabrication. Other previous publications [17-19] have mainly focused on the application of scaffolds without comparing the fabrication technique with the types of scaffolds.

A number of publications in the literature have focused on the use of bacteria cellulose than plant cellulose. At present, the use of plant cellulose compared to microbial cellulose is gaining more attention. This is as a result of the recent revolutions of fabrication techniques of micro- and nanoparticles and recent toxicity studies. This review presents recent updates of micro- and nanocellulose-based materials in scaffold development for tissue engineering applications. It gives a critical review and analysis of previous research work in scaffold fabrication techniques with micro- and nanocellulose. Detail study of the chronological development and deficiencies of scaffold evolution is reported along with the highlights of the prospective applications, and further research on micro- and nanocellulose-based scaffolds are recommended in this study.

\section{Plant Fibre Materials}

Cellulose can be isolated from plant or animal sources and is composed of repeating units of glucose. Plant fibres are defined as natural elongated materials isolated from plant cell walls that have a specific tubular composite structure with a stack of piles. Each pile consists of primary and secondary walls [20]. The chemical composition of plant fibre is dependent on the source of fibre [21]. Common sources of plant fibres are cotton, sisal, and hemp [21]. Plant cellulose exists in combination with 
other components, mainly hemicellulose and lignin [22]. Therefore, during the isolation of cellulose, these compounds must be removed or at least eliminated. Lignin is bonded with hemicellulose and cellulose by ester linkages and hydrogen bonds. Lignin present in the cell walls of cellulosic fibres has been essentially responsible for the structural integrity of these fibres together with cellulose. Thus, natural or vegetable fibres in most cases (except for cotton) have been termed as lingo-cellulosic fibres [23]. The complex structure of lignin linkages with hemicellulose forms a matrix around cellulose molecules and results in it being very tough and difficult to break the network. The connection between the sugar monomer formed long chains and the interaction between these chains generates strong intermolecular forces between them. The high linearity of the cellulose molecule also results in a tightly packed nature of cellulosic fibres [24]. The polymeric structure and linkages of the polysaccharide resulted in the fibre's strong intermolecular forces between its chains. The high linearity of the cellulose molecule accounted for the crystalline nature of cellulosic fibres [24].

Many procedures have been developed to produce cellulose fibre, for example, the preparation of spinnable solutions from cellulose using different solvents and conditions [25]. Viscose, modal, or lyocell cellulosic fibres can be generated with different physical properties such as the degree of crystallinity, molecular orientation, and chemical properties (adsorption of water and dyes) [26]. These fibres are usually produced with a significant number of inorganic additives, which are embedded inside the cellulosic fibres. The embedding of inorganic particles is essential to the creation of new fibres with different functional properties. The embedded inorganic particles act as the carrier of the functional properties. Cellulosic fibres are extensively used in many applications such as the manufacture of different types of apparel due to its comfort and ability to absorb moisture, making it comfortable against the skin [27]. In most cases, cellulosic fibres have been extensively blended with other polymeric fibres such as polyester and spandex, especially in the manufacturing of shirting.

\subsection{Cellulose Fibre Architecture}

Cellulose is a natural polysaccharide and consists of repeating units of monomer glucose connected through $(1,4)$ beta $D$ linkages. Plant biomass is composed of cells surrounded by primary and secondary cell walls. Cellulose and hemicelluloses are the main components of plant cell walls and form $34-75 \%$ of the primary cell wall and $50-80 \%$ of the secondary cell wall [28]. The aggregation of many cellulose molecules form fibrils. The fibril bundles combine to form cellulose fibres. The fibrils have both crystalline (ordered) and amorphous (disordered) regions that are the main reinforcement segment for plants, trees, algae, some marine creatures, and bacteria [29]. Bacterial cellulose is a type of cellulose produced by certain bacteria such as Acetobacter xylinum. Acetobacter xylinum is an extracellular product and a unique form of cellulose produced in nature. It is very pure cellulose with a narrow size distribution and high crystallinity [30]. Table 1 presents the main differences between plant-based cellulose and bacterial cellulose.

Table 1. Differences between plants and bacterial cellulose.

\begin{tabular}{cccc}
\hline Properties & Plants Cellulose & Bacterial Cellulose & References \\
\hline Purity & Moderate to low & High & {$[31]$} \\
\hline Crystallinity degree & $54-88 \%$ & $65-79 \%$ & {$[32]$} \\
\hline Degree of polymerization & Ranged from 500-15,000 & $800-10,000$ & {$[33]$} \\
\hline Availability & Highly available & Limited & {$[34]$} \\
\hline Industrial-scale production & Limited & Very limited & {$[34]$} \\
\hline
\end{tabular}

The purity of bacterial cellulose is higher than that of plant-based cellulose. However, bacteria cellulose and plant cellulose have similar crystallinity, water retention capability, tensile strength, and biocompatibility. These characteristics of isolated cellulose are dependent on the source and method of preparation [35]. Figure 1 presents the hierarchical structure of cellulose, cellulose nanocrystals, 
and micro/nanofibrillated cellulose (the upper part of the figure), while the lower part presents the structure of bacterial cellulose.

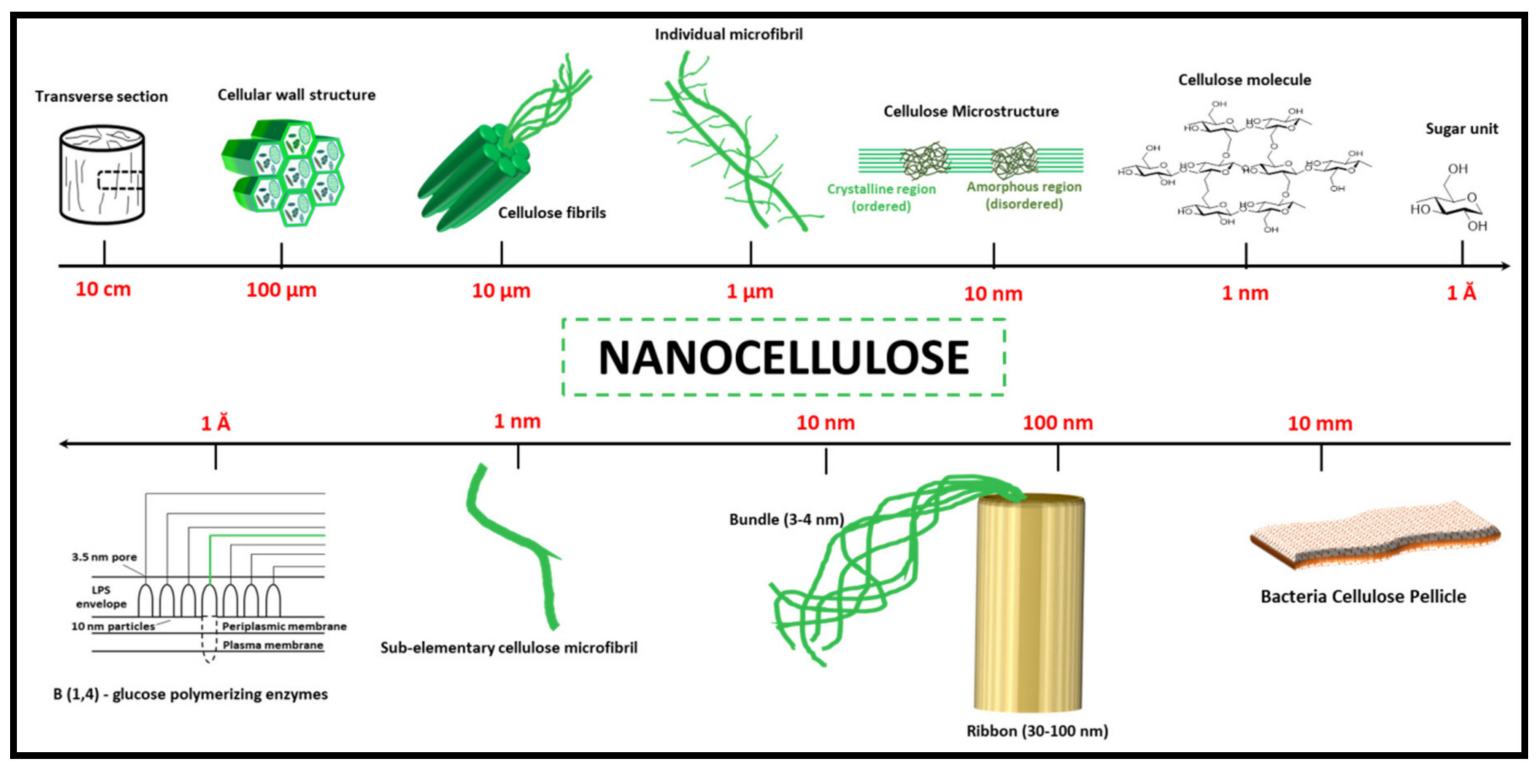

Figure 1. The hierarchical structure of cellulose. The upper part: plant cellulose; the lower part: bacterial cellulose. Adapted from [35]. Copyright, 2014, Elsevier.

Cellulose macromolecules are assembled in the semi-crystalline filament. The macromolecules consist of microfibres and nanofibres. The three-carbon monomeric units in the cellulose chain are bonded to the hydroxyl groups [36]. The hydrogen bonds play an important role in the structure of cellulose and the physicochemical properties of the molecule. The bond between a group of cellulose chains leads to the formation of micro-fibrils, which are jointly grouped to form typical cellulose fibres. Two different ends of the microfibrils in each cellulose polymeric chain possess carbonyl functionality and a supplementary hydroxyl group in carbon number 4. Stiffening of the cellulose chain has been a direct result of the banned free rotation of the cellulose rings by hydrogen bonds along with their linked-glycosidic bonds. However, the interactions of the van der Waals and hydrogen bonds lead to the formation of either crystalline ordered regions or amorphous disordered regions of the unique structure of cellulose [37]. The crystalline form has been known as type I, or cellulose I, and consists of a mixture of alpha-cellulose, beta-cellulose, triclinical structure, and monoclinical structure. Cellulose II is irreversible thermodynamically and more stable than cellulose I. Cellulose II can be prepared by treating the polymer with a concentrated alkaline solution such as sodium hydroxide. Different treatments of cellulose will lead to the generation of other crystal polymorphs such as cellulose III, IIIII, IVI, and IV [38].

The term microcellulose describe all forms of cellulose materials with diameters in the micrometre range, typically from $1 \mu \mathrm{m}$ to $1000 \mu \mathrm{m}$, while nanocellulose describes the forms of cellulose-containing dimensions in the nanoscale (1-100 nm) [39]. However, both micro- and nanocrystalline cellulose can be produced by the extraction of crystalline regions from native cellulose using acid hydrolysis of disordered/amorphous regions, which link together assemblies of microfibrils [40]. Depending on the conditions of extraction, the crystalline region of the microcellulose can significantly vary in size and aspect ratio. This usually results in different types of fibrils, crystalline, and particle sizes (which may be in micro- or nano-size). However, they are normally anisometric [39].

\subsection{Microcellulose Material Forms}

The micro-sized form of cellulose has two basic forms: micro fibrillated cellulose (MFC) and microcrystalline cellulose (MCC). The definition of these forms is based on the features in the physical 
and microstructural view of the material. These views differentiate the properties of each form and their effect when used as reinforcement in materials. Figure 2 shows the scanning electron microscope (SEM) images of the MFC and MCC forms. Cellulose microfibrils are composed of 18 or 24 cellulose chains with a variety of cross-sectional shapes, which are the original structure present in the natural plant [41]. MFC is produced from lignocellulosic biomass by mechanical treatment. The size distribution of MFC is wide, even if some fibres have diameters in the nanoscale. Microcrystalline cellulose (MCC) has been described as a purified, partially depolymerized cellulose. It has been sourced and isolated from woody and non-woody lignocellulosic materials and purified cotton linters [42].

It has been reported that cellulose microfibrils vary in size from 0.2 to $374 \mu \mathrm{m}$. The micro-fibrillated cellulose chain aggregates together to form macro-fibrillated chains [43]. However, microcrystalline cellulose has been reported as the non-amorphous region of the chain, which is divided into a well-organized crystal-surface and poorly organised crystal interior [44]. However, the amorphous or non-crystalline region has been attributed to mechanical damage or wood pulping treatment rather than the state of native cellulose [42]. Micro-fibrillated cellulose is a micro-size fibrillated unit obtained through a fibrillation process of cellulose fibres using mechanical shearing with or without enzymatic or chemical pre-treatment [45]. The small diameter of 3D fibrils allowed them to form a network of microfibres with an extremely large surface area. Micro-fibrillated cellulose has the typical structure of cellulose with crystalline and amorphous regions. It possesses a high viscosity and yield stress. It is sheer thinning and has a high water-holding capacity. The size distribution of these fibres are wide, their length varies from 50 to more than $900 \mu \mathrm{m}$, and the width from nano-size in some cases to micro-size [46]. Nie et al. [47] isolated micro-fibrillated cellulose from Artemisia Vulgaris Bast, using alkali degumming and TEMPO (2,2,6,6-tetramethylpiperidine-1-oxyl) chemical treatment. The authors reported an average length of $850.6 \mu \mathrm{m}$ and a diameter of $14.4 \mu \mathrm{m}$. Micro-fibrillated cellulose is often used in many industrial applications including biomedical and scaffold fabrication [48].

MCC is often prepared by the acid hydrolysis of cellulose at high temperatures. The reactive amorphous regions of the cellulose are selectively hydrolysed, which releases the crystallites out of the chains. The results of the acid hydrolysis of the aqueous suspension have often been referred to as microcrystalline cellulose suspensions [23]. The particle size of isolated microcellulose materials is dependent on the cellulose source, pre-treatment operation, and the preparation process. Recently, Nie et al. [47] used an alkali degumming process to prepare micro fibrillated cellulose and a significantly small particle size was obtained, compared to the result of Tamaddon and Hosseinzadeh [5]. Furthermore, microcrystalline cellulose has been prepared with different techniques. Table 2 shows the comparison between the obtained particle size and preparation technique. 

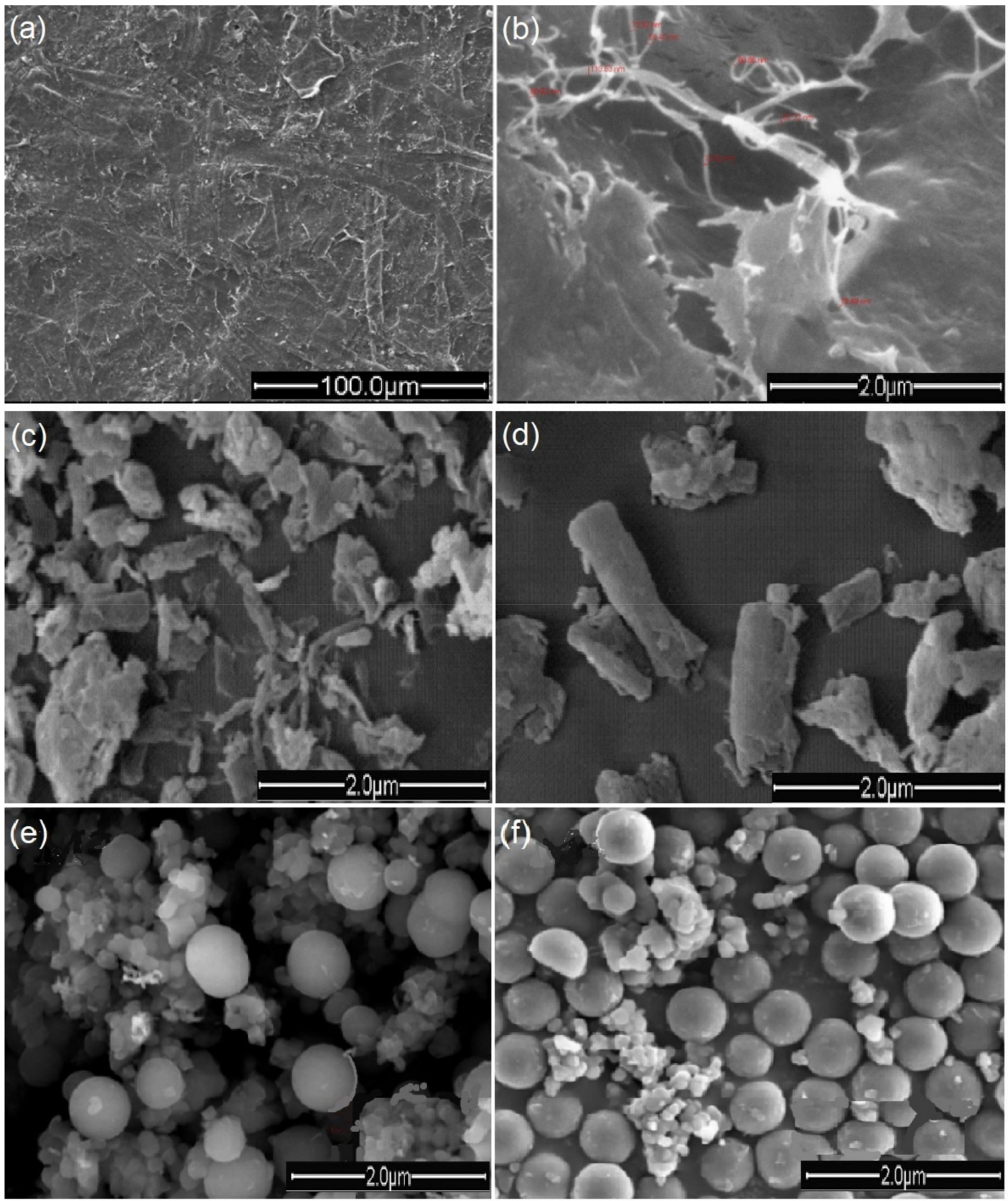

Figure 2. Scanning electron microscope (SEM) images of different forms of microcellulose materials. $(\mathbf{a}, \mathbf{b})$ Surface of micro-fibrillated cellulose from the bleached cotton stalk [49], (c,d) the surface of micro-microcrystalline cellulose from the cotton stalk [50], (e,f) microcellulose particles of cotton, adapted [51].

Table 2. Material and process of microcellulose materials.

\begin{tabular}{|c|c|c|c|}
\hline Material & Preparation Process & Particle Size & References \\
\hline MFC & Acid hydrolysis & $9-16 \mu \mathrm{m}$ & [5] \\
\hline MCC & $\begin{array}{l}\text { Treatment of } \\
\text { urea/NaOH }\end{array}$ & $0.05-0.6 \mu \mathrm{m}$ & [52] \\
\hline MCC & Enzymatic hydrolysis & $0.01-200 \mu \mathrm{m}$ & [53] \\
\hline MCC & Catalytic hydrolysis & $8.68-31.1 \mu \mathrm{m}$ & [54] \\
\hline MFC & $\begin{array}{l}\text { Alkali degumming } \\
\text { process }\end{array}$ & $0.25-0.30 \mu \mathrm{m}$ & [47] \\
\hline MCC & Acid hydrolysis & 20 to $374 \mu \mathrm{m}$ & [43] \\
\hline
\end{tabular}


Modification of hydrolysis conditions such as temperature, time, and acid concentration has been reported to have a significant impact on the degree of polymerisation of MCC. However, hydrolysis conditions have very little impact on the degree of crystallinity of MCC. Additionally, the moisture within the pores of MCC has a significant effect on its physical and chemical properties. It also has a significant impact on its internal lubricant, which in turn affected its tensile strength, compaction, and even viscoelastic properties. The heat stability and relatively constant viscosity at different temperatures of MCC suspensions have been established from previous research. Its excellent mouth-feel properties have also been explored in the pharmaceutical and food industries to extend starches, control ice crystal formation, the binder in pharmaceutical tablets, confections, stabilise foams, and cosmetics [55]. Table 3 presents the progressive chronological studies of microcellulose-based materials.

Table 3. Chronological summary of the research trends on microcellulose-based materials.

\begin{tabular}{|c|c|c|}
\hline Researchers & Progress & References \\
\hline Payen (1839) & The first-time isolation of cellulose as the principal constituent of wood. & [56] \\
\hline Schonbein (1845) & The first invention of cellulose esters. & [57] \\
\hline Ranby (1949) & $\begin{array}{l}\text { The first production of microcellulose and nanocrystals with acid hydrolysis } \\
\text { of cellulose fibres dispersed in water. }\end{array}$ & [58] \\
\hline Ranby (1951) & $\begin{array}{l}\text { First synthesised colloidal suspensions of cellulose with acid-catalysed } \\
\text { degradation of cellulose fibres. }\end{array}$ & [23] \\
\hline Mukherjee et al. (1952) & First TEM images of cellulose materials. & [59] \\
\hline Battista and Smith (1955) & Microcrystalline cellulose first discovery. & [60] \\
\hline Colvin et al. (1960) & Formation of micro-fibrillated cellulose in suspensions of Acetobacter xylinum. & [61] \\
\hline Halliwell et al. (1965) & $\begin{array}{l}\text { Soil micro-organisms cellulolytic enzymes to re-precipitate cellulose and } \\
\text { preparing it by hydrolysis of fibrous cotton. }\end{array}$ & [62] \\
\hline Heyn et al. (1966) & $\begin{array}{l}\text { Extensively study of the microcrystalline structure of cellulose in cell walls of } \\
\text { plants fibres as revealed by negative staining of sections. }\end{array}$ & [63] \\
\hline Toshkov et al. (1976) & Development of various method to produce microcrystalline cellulose. & [64] \\
\hline Kobayashi and Shoda (1992) & First full chemically synthesised cellulose (non-biosynthetic path). & [65] \\
\hline Revol et al. (1998) & $\begin{array}{l}\begin{array}{l}\text { Development of cellulose-based solidified liquid crystals for various optical } \\
\text { applications. }\end{array}\end{array}$ & [66] \\
\hline Nakagaito \& Yano (2004) & Applying of cellulose microfibril for semi-structural applications & [67] \\
\hline $\begin{array}{l}\text { Kulpinski (2005), Viswanathan } \\
\text { et al. (2006) }\end{array}$ & Electrospinning of pure cellulose. & [59] \\
\hline Henriksson et al. (2007) & $\begin{array}{l}\text { Preparation of micro-fibrillated cellulose nanofibres with an environmentally } \\
\text { friendly method for enzyme-assisted. }\end{array}$ & [68] \\
\hline Nyström et al. (2010) & $\begin{array}{l}\text { Development of nanocellulose polypyrrole composite based on } \\
\text { micro-fibrillated cellulose from wood. }\end{array}$ & [69] \\
\hline Shao et al. (2015) & $\begin{array}{l}\text { Use of micro-fibrillated cellulose/lignosulfonate blends hydrogel rheology on } \\
\text { 3D printing. }\end{array}$ & [70] \\
\hline Alavi et al. (2019) & $\begin{array}{l}\text { Modifications of microcrystalline cellulose for antimicrobial and wound } \\
\text { healing applications. }\end{array}$ & [71] \\
\hline
\end{tabular}

\subsection{Nanocellulose Material Forms}

Nanocellulose materials have been classified into two main classes. Cellulose nano-objects, which include materials with one, two, or even three external dimensions in the nanoscale $(1-100 \mathrm{~nm})$, and nanostructured cellulose materials with an internal composition of inter-related constituent parts in which one or more of these parts is in the nanoscale. Cellulose nano objects include cellulose nanocrystals, cellulose nanofibrils (CNFs), and cellulose nanoparticles. At the same time, nanostructured cellulose materials include cellulose microfibrils, micro-fibrillated cellulose, and bacterial cellulose [40]. Nanocellulose is often used by researchers to enhance the strength of biomaterials. Nanocellulose possesses high mechanical strength and environmental sustainability [72]. Many researchers have categorised nanocellulose materials into three main types (Figure 3): 
nanofibrillated cellulose, nanocrystals, and nanoparticles [73]. These three types have a relatively similar chemical composition, but different degrees of crystallinity, particle size, and morphological properties [3].

Soyekwo et al. [74] describes nanofibrillated cellulose (NFC) as long flexible nano-size fibres, 1-100 $\mathrm{nm}$ in diameter and 500-2000 $\mathrm{nm}$ in length, and chemically composed of 100\% cellulose with both crystalline and amorphous regions. The average size of NFC particles varies and depends on the method of preparation. Recently, NFC has been economically produced from various cellulose sources such as pulp and cotton via a series of surface modifications to enhance their performance in the desired application [75]. A single nanofibre has outstanding stiffness as well as good chemical and thermal stability. Over the last decade, NFC use in scaffold fabrication has gained significant interest, and this is due to their low coefficient of thermal expansion, high Young's modulus, high strength, biocompatibility, low weight, and renewability [76]. The NFC dispersed solution and hydrogel precursor have been cross-linked with a relatively facile and mild method for hydrogel scaffold for tissue engineering [77]. At present, tissue scaffolds using a NFC aerogel have been widely fabricated [3].
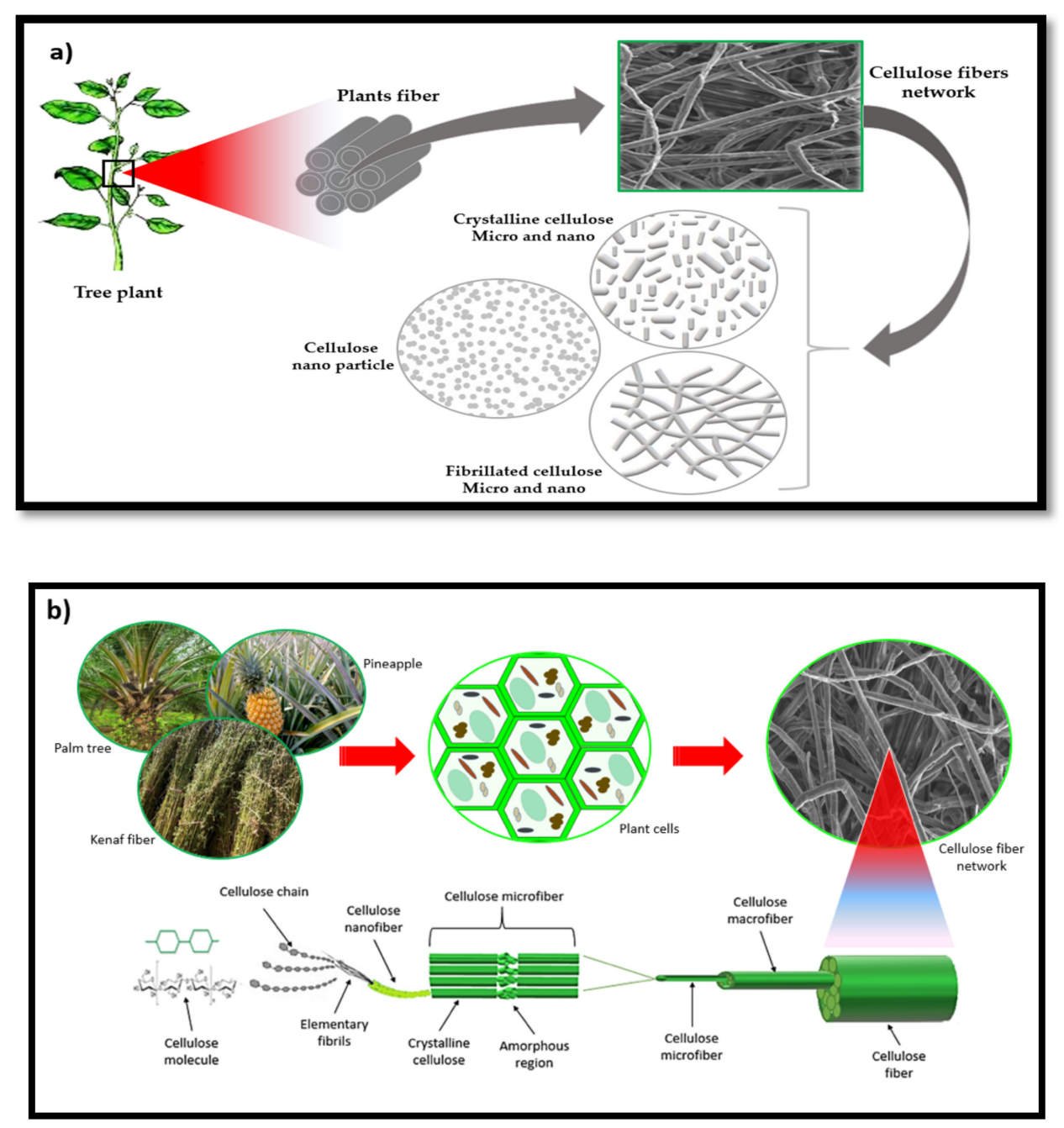

Figure 3. (a) Classification of nanocellulose materials based on microstructural forms. (b) Schematic diagram of different scientific forms and structure of cellulose fibre.

Nanocrystalline cellulose (NCC) has been extracted from cellulose fibres by acid hydrolysis and characterised with high strength [78]. NCC has otherwise been called cellulose nano-whiskers or cellulose nanocrystals [79]. Isolated NCC has been described as shorter and has a rod-like shape compared to NFC. Figure 4 shows the SEM images of the nanocellulose materials. The acid hydrolysis 
method used by [76] was to reduce the average diameter using an ultra-turrax and micro-fluidizer. A similar diameter has been obtained by [80]. The diameter of NFC is diverse based on the preparation process, as presented in Table 4. In [81], the authors obtained NFC with a small diameter of $15 \mathrm{~nm}$ by using the blending method, which was smaller than the one obtained with the electrospinning process (70-130 $\mathrm{nm})$ by [82].
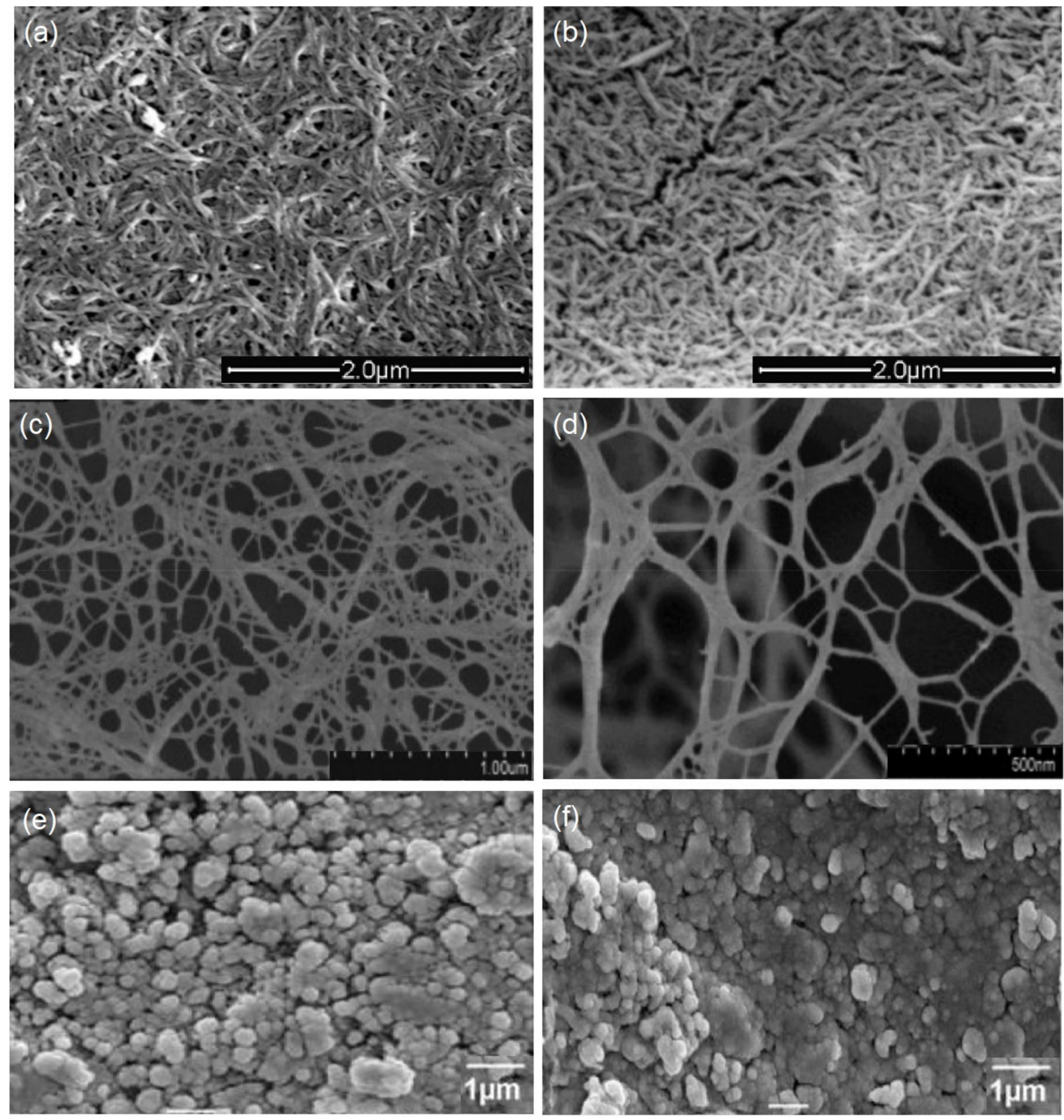

Figure 4. Scanning electron microscope (SEM) images of different forms of nanocellulose materials. (a,b) Nanocrystalline cellulose obtained from cotton and cotton stalk pulps, adapted from [83]. (c,d) Surface of nanofibrillated cellulose from cotton, adapted from [84]. (e,f) The surface of cellulose nanoparticles from cotton, adapted from [85]. 
Table 4. Nanocellulose material preparation technique.

\begin{tabular}{cccc}
\hline Material & Preparation Process & Particle Diameter & Reference \\
\hline Cellulose nanofibre & Ball milling & $100 \mathrm{~nm}$ & {$[86]$} \\
Cellulose nanofibre & Electrospinning & 70 to $130 \mathrm{~nm}$ & {$[82]$} \\
Nanocrystalline cellulose & High-intensity ultrasonication & 10 and $20 \mathrm{~nm}$ & {$[87]$} \\
Cellulose nanofibre & Blending Method & $15-20 \mathrm{~nm}$ & {$[81]$} \\
Nanocrystalline cellulose & Acid hydrolysis & $10 \mathrm{~nm}$ & {$[88]$} \\
Cellulose nanofibre & Twin-Screw Extrusion & $30 \mathrm{~nm}$ & {$[89]$} \\
Nanocrystalline cellulose & Acid hydrolysis & $85 \mathrm{~nm}$ & {$[90]$} \\
\hline
\end{tabular}

Over the past few years, NCC has been investigated for many medical applications including tissue-engineering scaffolds. Its biocompatibility and other properties that are similar to NFC make it suitable for in vitro and in vivo usage. Shaheen et al. [91] fabricated a NCC with a high stiffness similar to titanium, copper, and bronze materials used in bone implants. Furthermore, the high aspect ratio, surface area, and crystallinity as well as low elongation at break, in turn, support its strength for 3D scaffolds as a load-bearing material [92].

Cellulosic nanoparticles (CNPs) are another cellulose-based nano-sized short structure material of cellulose. Gu et al. [93] characterised CNPs and described them as short needle or ribbon-like particles. Furthermore, their properties are dependent on the source of the cellulose, and it appears as a rod or spherical shape. CNPs have been prepared by various hydrolysis methods, the removal of the amorphous regions of cellulose, and dispersal of the crystalline region [94]. Table 5 presents the progress of studies among the nanocellulose-based materials.

Table 5. Chronological summary of the evolutionary research trend on nanocellulose-based scaffold materials.

\begin{tabular}{|c|c|c|}
\hline Researchers & Progress & References \\
\hline Ranby (1949) & $\begin{array}{l}\text { The first production of microcellulose and nanocrystals with acid } \\
\text { hydrolysis of cellulose fibres dispersed in water. }\end{array}$ & [58] \\
\hline Turbak and Herrick (1983) & $\begin{array}{l}\text { First isolation of nanofibrillated cellulose with mechanical } \\
\text { homogenisation of wood. }\end{array}$ & [95] \\
\hline $\begin{array}{l}\text { Favier et al. } \\
\quad(1995)\end{array}$ & $\begin{array}{l}\text { The first report demonstrating the reinforcing effect of cellulose } \\
\text { nanocrystals. }\end{array}$ & [59] \\
\hline Azizi Samir et al. (2004) & $\begin{array}{l}\text { Isolation of cellulose whiskers reinforced nanocomposites from an } \\
\text { organic medium suspension. }\end{array}$ & [96] \\
\hline Svagan et al. (2007) & $\begin{array}{l}\text { Preparation of cellulose nanofibres bio-foams from wood pulp-based on } \\
\text { amylopectin-rich potato starch. }\end{array}$ & [97] \\
\hline Henriksson et al. (2008) & Development of Nano-paper from cellulose nanofibre suspensions. & [98] \\
\hline Fang et al. (2009) & $\begin{array}{l}\text { Fabrication of hydroxyapatite/bacterial cellulose nanocomposite } \\
\text { scaffolds for the cultivation of human bone marrow stromal cells. }\end{array}$ & [99] \\
\hline Rosa et al. (2010) & $\begin{array}{l}\text { Isolation and characterisation of cellulose nanofibre from coconut husk } \\
\text { fibres. }\end{array}$ & [100] \\
\hline $\begin{array}{l}\text { Crotogino } \\
(2012)\end{array}$ & $\begin{array}{l}\text { First pilot plant for cellulose nanomaterials production by Innventia in } \\
\text { Sweden. }\end{array}$ & [101] \\
\hline Dugan et al. (2013) & $\begin{array}{l}\text { Development of bacterial cellulose scaffolds and cellulose nanofibre for } \\
\text { tissue engineering applications. }\end{array}$ & [102] \\
\hline Zhou et al. (2013) & $\begin{array}{l}\text { Development of electrospun cellulose nanocrystals-based scaffolds for } \\
\text { bone tissue engineering, reinforcing maleic anhydride grafted PLA. }\end{array}$ & [103] \\
\hline Yang et al. (2015) & $\begin{array}{l}\text { Fabrication of cellulose nanocrystal-based aerogels as universal 3D } \\
\text { lightweight substrates for supercapacitor materials. }\end{array}$ & [104] \\
\hline Liu et al. (2016) & $\begin{array}{l}\text { Development of nanocellulose scaffolds with tunable structures to } \\
\text { support 3D cell culture }\end{array}$ & [105] \\
\hline Li et al. (2017) & $\begin{array}{l}\text { 3D printing of many aerogel structures from pure cellulose nanocrystal } \\
\text { with direct ink writing technique. }\end{array}$ & [106] \\
\hline Apelgren et al. (2019) & $\begin{array}{l}\text { In vivo formation of human cartilage in 3D bio-printed constructs with } \\
\text { a novel bacterial nanocellulose bio-ink. }\end{array}$ & [107] \\
\hline
\end{tabular}




\section{Cellulose-Based Scaffolds in Biomedical Engineering}

Tissue-engineering technology has advanced with the potential to grow desired cells, tissues, or even whole organs. Regeneration of damaged cells, tissues, or organs of the human body with natural and synthetic polymers has been achieved to a great extent [108]. The role of natural polymers such as cellulose as a replacement of synthetic polymers has been on the increase in biomedical and tissue engineering applications [109]. Langer and Vacanti in the 1990s were the first to describe and define the term "tissue engineering" and its effect of materials on the cells [110]. Since then, many publications and research have been undertaken to fabricate three-dimensional structured scaffolds for cells to adhere and proliferate. The advancement in tissue engineering has created an avenue for a new era in regenerative medicine. The discovery of rapid prototyping for part production has also enhanced the fabrication of complex scaffolds. Micro- and nanocellulose-based materials and hybrids have been used as bio-ink for 3D printing, which provides a unique methodology for the customisation of desirable biomedical scaffolds [106]. 3D scaffolds with controlled pore structure and orientation, shape, and size have been fabricated from different materials for the regeneration of a variety of cells such as bone regeneration [111], muscle regeneration [112], ligament regeneration [113], and tendon regeneration [114].

\subsection{Development of Cellulose-Based Scaffolding}

Cellulose-based materials were among the first developed materials for scaffold forming due to cellulose immune response (biocompatibility) and better overall interactions with various cell types compared to many synthetic polymers [115]. However, a key need for effective tissue engineering is to provide the cell's growth and proliferate requirements, which is the main role of the scaffolds [116]. The purpose of scaffolds, as reported by Berthiaume et al. [116], is their ability to provide a suitable environment for the attachment and migration of cells, biochemical retention, diffusion of both nutrients towards the cells, and mechanical support. Among the natural polymers often used in tissue scaffold fabrication are proteins (collagen and fibrin) and polysaccharides (cellulose and chitosan). Several reports on cellulose-based scaffolds have reported biocompatibility and less or no cytotoxicity. However, there remain issues with potential immunogenicity in some types of tissues.

\subsection{Method of Preparation of Micro- and Nanocellulose-Based Scaffolds}

Fabrication of scaffolds has been described as a major area of tissue engineering, regenerative medicine, and biomedical research [117]. Previous research work in this area has been focused on restoring, improving, or maintaining the functionality of the growing cells. Scaffolds have been used in tissue engineering technology to provide a multi-layered matrices nested network for growing cells, which is required for growth, proliferation, and cell differentiation [118]. Scaffolds have also been utilised to facilitate the repair of damaged and defective tissues such as skin during burn injuries. Furthermore, fabricated scaffolds for the growth of whole organs have also been proposed. Many organs have been suggested for growing in scaffolds such as kidneys or livers with 3D printing technology. With a view to achieving good mechanical support in tissue repair, in vitro growing, and proliferation of cells, many fabrication techniques have been designed, as summarised in Figure 5. Eltom et al. [118] classified the design of a functional scaffold into two parts or stages: the micro-scale level, also called the cell level, and the macro scale, also known as the tissue level. The cell level design involved consideration of the scaffolding functionality in the environment of its use and function of cells. The macro-scale level or tissue level involves tissue construction in maintaining the adequate transportation of nutrients and possesses the mechanical properties of multicellular tissue. 


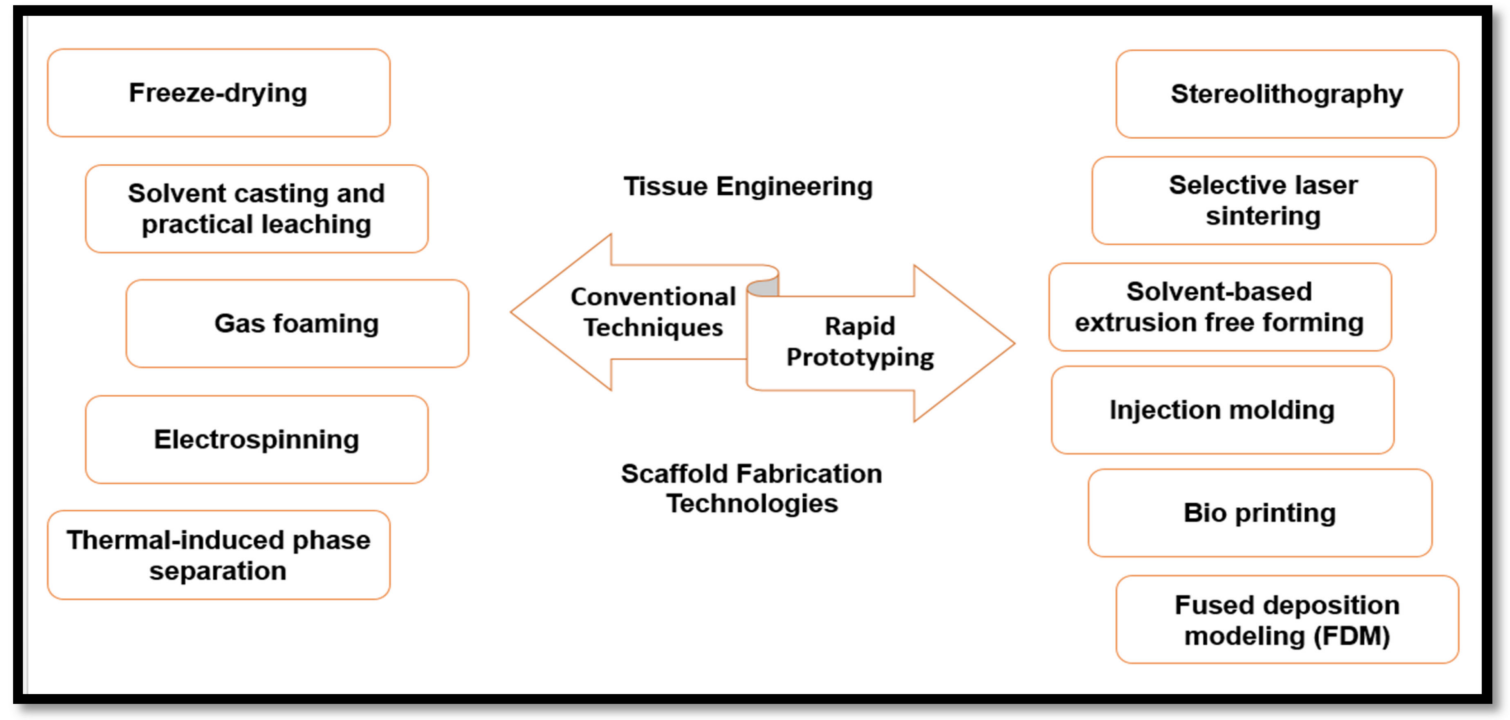

Figure 5. Types and classification of scaffold fabrication technologies of micro- and nanocellulose-based materials.

\subsubsection{Conventional Techniques for Micro- and Nanocellulose-Based Scaffold Fabrication}

Several researchers have developed novel techniques for the fabrication of different shapes of 3D polymeric scaffolds [115]. A significant number of scaffolds have been designed and fabricated with the techniques of that era, known as conventional techniques for scaffold fabrication. These techniques were done with consideration of the bulk, surface properties of the materials and the proposed function of the scaffold. Freeze-drying has been one of the most widely used traditional techniques in scaffold fabrication for biomedical applications. The technique uses water and ice crystals instead of organic solvents, and it does not require high temperatures. Thus, the pore size of the resulting scaffolds is manageable, but it is still not possible to obtain homogenous pores. However, the authors in [119] reported some drawbacks in this technique such as energy consumption and irregular sized pores. Table 6 (Part A) shows a summary of conventional techniques used in the scaffold fabrication of microand nanocellulose-based material.

Table 6. Conventional and rapid prototyping techniques for scaffold fabrication of micro- and nanocellulose-based materials.

\begin{tabular}{|c|c|c|c|}
\hline \multicolumn{4}{|c|}{ Part A: Conventional Techniques for Scaffold Fabrication } \\
\hline Technique & Operational Condition & Principal & Reference \\
\hline Freeze-drying & $\begin{array}{l}\text { Pre-freezing }-20^{\circ} \mathrm{C} \text { for } 12 \mathrm{~h} \text {, } \\
\text { then freeze-drying at }-80^{\circ} \mathrm{C} \\
\text { for } 48 \mathrm{~h}\end{array}$ & $\begin{array}{l}\text { Using aqueous crystals instead of an organic } \\
\text { solvent and does not require high temperatures. }\end{array}$ & [120] \\
\hline $\begin{array}{l}\text { Solvent casting and } \\
\text { practical leaching }\end{array}$ & $70{ }^{\circ} \mathrm{C}$ to dissolve the salts & $\begin{array}{l}\text { Different solvents and salt particles used, which } \\
\text { then evaporated leaching out the salts. }\end{array}$ & [121] \\
\hline Gas foaming & $\begin{array}{l}\mathrm{CO}_{2} \text { at } 65 \text { bar, } 70^{\circ} \mathrm{C} \text {, the } \\
\text { processing time of } 1 \mathrm{~h}\end{array}$ & $\begin{array}{l}\text { High temperature and organic solvents used in } \\
\text { dissolving \& inert gases to pressurise modelled it } \\
\text { until it saturated or full of gas bubbles. }\end{array}$ & [122] \\
\hline Electrospinning & High voltage power supply & $\begin{array}{l}\text { Charged threads of polymeric solution or polymer } \\
\text { melt are drawn by high voltage electricity. }\end{array}$ & [123] \\
\hline $\begin{array}{l}\text { Thermal-induced } \\
\text { phase separation }\end{array}$ & $\begin{array}{c}\text { Dissolved for } 8 \mathrm{~h} \text { at } 70^{\circ} \mathrm{C} \text { with } \\
300 \text { rpm magnetic stirring, } \\
\text { then water evaporation at } 100 \\
{ }^{\circ} \mathrm{C} \text {. }\end{array}$ & $\begin{array}{l}\text { Alteration of temperature to force phase separation } \\
\text { of the polymer solution, and then dried used to } \\
\text { form a nanoscale fibrous network. }\end{array}$ & [124] \\
\hline
\end{tabular}


Table 6. Cont.

\begin{tabular}{|c|c|c|c|}
\hline \multicolumn{4}{|c|}{ Part B: Rapid Prototyping Techniques for Scaffold Fabrication } \\
\hline Technique & Operational Condition & Principal & Reference \\
\hline Stereolithography & $\begin{array}{l}\text { UV-light }(365 \mathrm{~nm}, 1500 \mathrm{~W}) \text { for } \\
40 \mathrm{~s} \text {, then }-80{ }^{\circ} \mathrm{C} \text { for } 12 \mathrm{~h} \\
\text { followed by freeze-drying at } \\
\quad-68{ }^{\circ} \mathrm{C} \text { for } 48 \mathrm{~h}\end{array}$ & $\begin{array}{l}\text { Layer-by-layer printing of photosensitive liquid of } \\
\text { polymer with an ultraviolet laser until a } 3 \mathrm{D} \\
\text { scaffold fabricated. }\end{array}$ & [125] \\
\hline $\begin{array}{l}\text { Selective laser } \\
\text { sintering }\end{array}$ & $\begin{array}{l}\text { Laser scan speed } 39.8 \mathrm{~mm} / \mathrm{s} \text {, } \\
\text { laser power ranged from } 1.5 \text { to } \\
\text { 3.5 W. }\end{array}$ & $\begin{array}{l}\text { The selective laser used to sinter powdered } \\
\text { material in thin layers until a 3D scaffold fabricated. }\end{array}$ & [126] \\
\hline $\begin{array}{l}\text { Solvent-based } \\
\text { extrusion } \\
\text { free-forming }\end{array}$ & $\begin{array}{l}\text { Heating temperature of } 170{ }^{\circ} \mathrm{C} \\
\text { and air pressure of } 80 \mathrm{psi}\end{array}$ & $\begin{array}{l}\text { Discharging of liquid to solid transition through } \\
\text { solvent evaporation in the presence of a binder. }\end{array}$ & [127] \\
\hline Bioprinting & $\begin{array}{l}3 \mathrm{D} \text { printing was at } 70{ }^{\circ} \mathrm{C} \text {, then } \\
\text { freeze to }-70{ }^{\circ} \mathrm{C} \text { for } 12 \mathrm{~h} \\
\text { followed by freeze-drying. }\end{array}$ & $\begin{array}{l}\text { Fabrication of layer-by-layer, of selective powdered } \\
\text { material, then taking out the unbound powder, } \\
\text { yielding a complex 3D scaffold. }\end{array}$ & [128] \\
\hline $\begin{array}{l}\text { Fused deposition } \\
\text { modelling }\end{array}$ & $\begin{array}{l}\text { Printing temperature was } 210 \\
{ }^{\circ} \mathrm{C} .\end{array}$ & $\begin{array}{c}\text { Layer-by-layer deposition of polymeric materials } \\
\text { extruded through a nozzle to create 3D multiple } \\
\text { layers scaffolds. }\end{array}$ & [129] \\
\hline Injection moulding & At room temperature & $\begin{array}{l}\text { Special moulding machine used to melt and inject } \\
\text { the polymeric material into the mould, where it } \\
\text { cools and solidifies into the final part. }\end{array}$ & [130] \\
\hline
\end{tabular}

Solvent casting and particle leaching have also been used as another traditional technique in scaffolding. Kanimozhi et al. [131] compared freeze drying and salt leaching techniques in the fabrication of a composite cellulose scaffold. The result revealed that salt-leached scaffolds were easier to form into desired shapes. Furthermore, the results of the biocompatibility experiment showed that the salt leaching scaffold had better cell viability than the freeze-dried scaffold. Eltom et al. [118] described the salt leaching technique as the dissolution of the polymer in different solvents and salt particles. However, scaffolds produced by the salt leaching technique cannot guarantee the interconnectivity of pores due to the adjacent salt particles that are in contact with each other. The salt contact results in the inconsistent macrostructure and microstructure of the prepared scaffolds. Chen et al. [132] enhanced this method by combining particle leaching and freeze-drying techniques and by using pre-prepared ice particulates as the particle material. The authors reported that their scaffold possessed good mechanical strength handling, and had no effect on the cells' proliferation. This method has been used because of its low-cost and ability to build a highly porous 3D scaffold. Zubairi [133] studied the residual effect of sodium chloride on cell growth media and revealed that residual sodium chloride might be considered as too small to produce any adverse effect on cell growth. A bacterial cellulose scaffold was prepared using this technique, and field emission scanning electron microscopic analysis revealed a porous structure of the scaffold. It also exhibited a very high swelling ratio, indicating enhanced water absorption and nutrient exchange capacity. Moreover, an in vitro biocompatibility study indicated good cell adhesion, penetration, and proliferation [134].

The gas foaming technique makes use of high temperatures and organic solvents to dissolve the polymer. Inert gases are also used to pressurize the obtained polymer melt with water or fluoroform until saturated full gas bubbles have been formed [135]. The control of the pore size and interconnectivity in gas foaming is done by the variation of process parameters such as temperature, $\mathrm{CO}_{2}$ pressure, depressurization rate, and particle size of salt [136]. These parameters have a significant effect on the physical and mechanical properties of the cellulose scaffold. A pore size within the range of 116 to $418 \mu \mathrm{m}$ has been generated using this fabrication technique, and the porosity ranged between 69.8 and $92.3 \%$ [136].

The electrospinning method involves the use of high voltage electricity for scaffold fabrication. It has been reported by Li et al. [137] as a very complicated technique for the fabrication of nano-fibrous scaffolds. He et al. [138] used this method to fabricate cellulose nanocrystal based scaffolds and evaluated its potential use in tissue engineering. The scaffold exhibited good physical properties and mechanical properties. The technique was essentially nontoxic to human cells and enhanced 
rapid proliferation not only on the surface, but also deep inside the cellulose layers. However, many drawbacks have been reported regarding electrospinning. The drawbacks include the use of toxic solvents, low rigidity, difficulty in controlling pore size and pore shape, dependency on many variables and the densely packed fibres in two-dimensional (2-D) array, which may impede their applicability in tissue regeneration. [139].

Thermal-induced phase separation is a different method that involves alteration of temperature in forcing phase separation of the polymer solution. The solvent is eliminated with freeze or vacuum drying and this results in a porous, nanoscale fibrous network. This method has been used for the fabrication of many thermoplastic and polymeric based scaffolds [140]. Organic solvent residues in the scaffold are the main disadvantage of this method, which has been reported to affect the viability and proliferation of growing cells [124] The mechanical properties of the foams could be tuned by changing the overall porosity and the hard segment content of the polymer. Figure 6 shows a summary of the conventional techniques used in scaffold fabrication.

\subsubsection{Rapid Prototyping Techniques for Scaffold Fabrication}

Rapid prototyping techniques are manufacturing methods that make use of computer-aided design without the need for any tools or equipment. Rapid prototyping has often been referred to as solid free-form fabrication [141]. Table 7 (Part B) shows the summary and schematic drawing of the different rapid prototyping techniques.

Stereolithography is one of the rapid prototyping techniques used to manufacture solid 3D scaffolds. Stereolithography involves consecutively printing a layer-by-layer of photosensitive liquid resin with an ultraviolet laser until a 3D scaffold is fabricated [118]. Cellulose nanofibre (CNFs) composite scaffolds have been fabricated using this technique with high and tunable compressive modulus and high porosity of approximately $90 \%$. The authors reported that CNFs in the composite scaffolds played a significant role in structural shape integrity, porous structure, and mechanical strength. Additionally, the cytotoxicity experiment revealed that cells had good differentiation and viability [125]. Another rapid prototyping technique is known as selective laser sintering, like stereolithography. However, this method uses laser light instead of UV to sinter powdered material in thin layers. Selective laser sintering has been utilised to fabricate scaffolds from various polymeric materials including cellulose-based materials with excellent user control over the microstructures of the manufactured scaffolds [142]. In a study reported by Shuai et al. [143], the authors prepared a cellulose nanocrystal-based scaffold using the selective laser sintering technique. The scaffold was reported to possess good physical and mechanical properties with excellent capability of supporting cell adhesion, proliferation, and differentiation. The solvent-based extrusion free-forming technique is a powder-based rapid prototyping method, the principle of which has been the realisation of liquid to solid transition through solvent evaporation. This can done in the presence of a binder, which enables the incorporation of cells during the scaffold printing process [144,145]. Lu et al. [146] studied the factors affecting the structure of the scaffold with this technique and concluded that the solvent content of paste is the most important parameter that determines the filament's ability to span and retain the planned height [146]. Limited studies about using this technique in tissue engineering scaffold fabrication due to the effect of solvents on the growing cells makes the solvent-based extrusion free-forming technique less used in this field. 


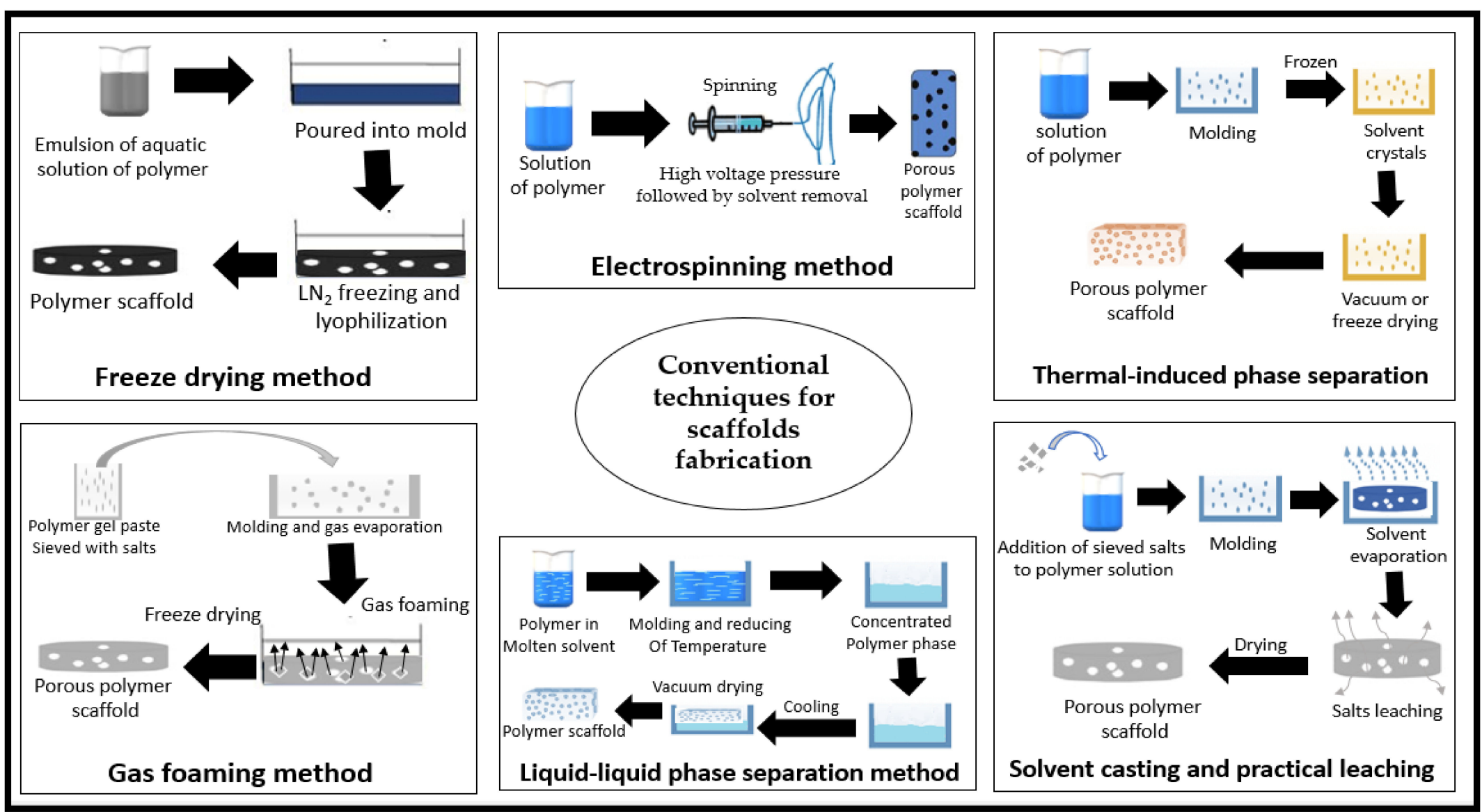

Figure 6. Schematic drawing of the biopolymer forming process of conventional techniques for scaffold fabrication. 
In 3D printing, 3D objects from designed computer models have been produced. The adhesive was printed with a selectively desired powdered material yielding a complex 3D object from the desired powder material [147,148]. This method was improved by Xu et al. [149] in terms of stability and fidelity by cross-linking the polymer with other auxiliary materials, which showed prospects in terms of skin repair and wound healing. Printing of biomaterial using 3D printers utilised in the fabrication of 3D scaffolds from different biomaterials with solvent-free, aqueous-based systems Bio 3D printing has been classified into cellular and acellular printing [150]. Acellular bio 3D printing has been used in the manufacture of scaffolds alone without involving target cells, resulting in higher accurate scaffold dimensions with greater shape complexity. In contrast, cellular bio 3D printing involves the integration of the desired cells and other required growth agents with the biomaterials during the printing process, resulting in a high speed of printing process [135].

Fused deposition modelling is another recent technique in scaffold fabrication, which uses computer-controlled extrusion of desired materials to create 3D multiple layer scaffolds. By using this technique, it is possible to obtain cellulose-based scaffolds with $70 \%$ porosity and a fully interconnected network of pores, and the porosity could be increased by altering the parameters. The authors reported pore sizes ranging from 200 to $500 \mu \mathrm{m}$, with excellent mechanical properties. Biocompatibility experiments have shown that cells were viable and that there were no signs of cellular death even after three weeks of culture [151]. The technique has limitations in its application to biopolymers; however, it has been using a low temperature and can be used in designing scaffolds under the different aspects of fabrication [118]. Figure 7 shows a summary and schematic drawing of the different rapid prototyping techniques.

The biggest advantage of rapid prototyping techniques over conventional preparation techniques is the ability to individualise application needs to efficiently apply scaffolds. Furthermore, using rapid prototyping, the scaffold shape can be controlled as well as the inner pore structure with high reproducibility. Table 7 highlighted the difference between rapid prototyping and conventional preparation techniques.

Table 7. Comparison between conventional and rapid prototyping techniques for scaffold fabrication.

\begin{tabular}{|c|c|c|c|}
\hline Functionality & $\begin{array}{c}\text { Conventional } \\
\text { Techniques }\end{array}$ & Rapid Prototyping Techniques & Reference \\
\hline $\begin{array}{c}\text { Scaffold development time \& } \\
\text { computer aid }\end{array}$ & $\begin{array}{c}\text { Relatively slow without } \\
\text { computer aid }\end{array}$ & $\begin{array}{c}\text { Rapid preparation with } \\
\text { computer-aided development }\end{array}$ & [152] \\
\hline $\begin{array}{l}\text { Manpower or technicians } \\
\text { requirements }\end{array}$ & $\begin{array}{l}\text { Require technicians and } \\
\text { more manpower needed }\end{array}$ & $\begin{array}{l}\text { Minimize manpower due to } \\
\text { computer-controlled fabrication }\end{array}$ & [147] \\
\hline Scaffold homogeneity & $\begin{array}{c}\text { Not able to develop } \\
\text { homogeneous structures }\end{array}$ & $\begin{array}{l}\text { Homogeneous structures can be } \\
\text { easily developed }\end{array}$ & [153] \\
\hline $\begin{array}{l}\text { Control the internal } \\
\text { microstructure of scaffolds }\end{array}$ & $\begin{array}{c}\text { Difficult or able to } \\
\text { control the internal } \\
\text { structures }\end{array}$ & $\begin{array}{l}\text { The internal structures can be } \\
\text { easily controlled }\end{array}$ & [154] \\
\hline Scaffold porosity & $\begin{array}{l}\text { Irregular pores shape } \\
\text { and insufficient } \\
\text { interconnectivity }\end{array}$ & Regular and interconnected pores & [155] \\
\hline $\begin{array}{l}\text { Effects on scaffold } \\
\text { cytotoxicity }\end{array}$ & $\begin{array}{l}\text { More effect on cells due } \\
\text { to solvent residue }\end{array}$ & $\begin{array}{l}\text { Less effect on cells, no solvent } \\
\text { residue }\end{array}$ & [153] \\
\hline $\begin{array}{l}\text { Ability to design accurate \& } \\
\text { desirable shapes }\end{array}$ & $\begin{array}{l}\text { Difficult to prepare the } \\
\text { desirable shape }\end{array}$ & $\begin{array}{l}\text { Easy to prepare even complex } \\
\text { shapes }\end{array}$ & [156] \\
\hline Cost of production & High cost of production & Low cost of production & [141] \\
\hline
\end{tabular}




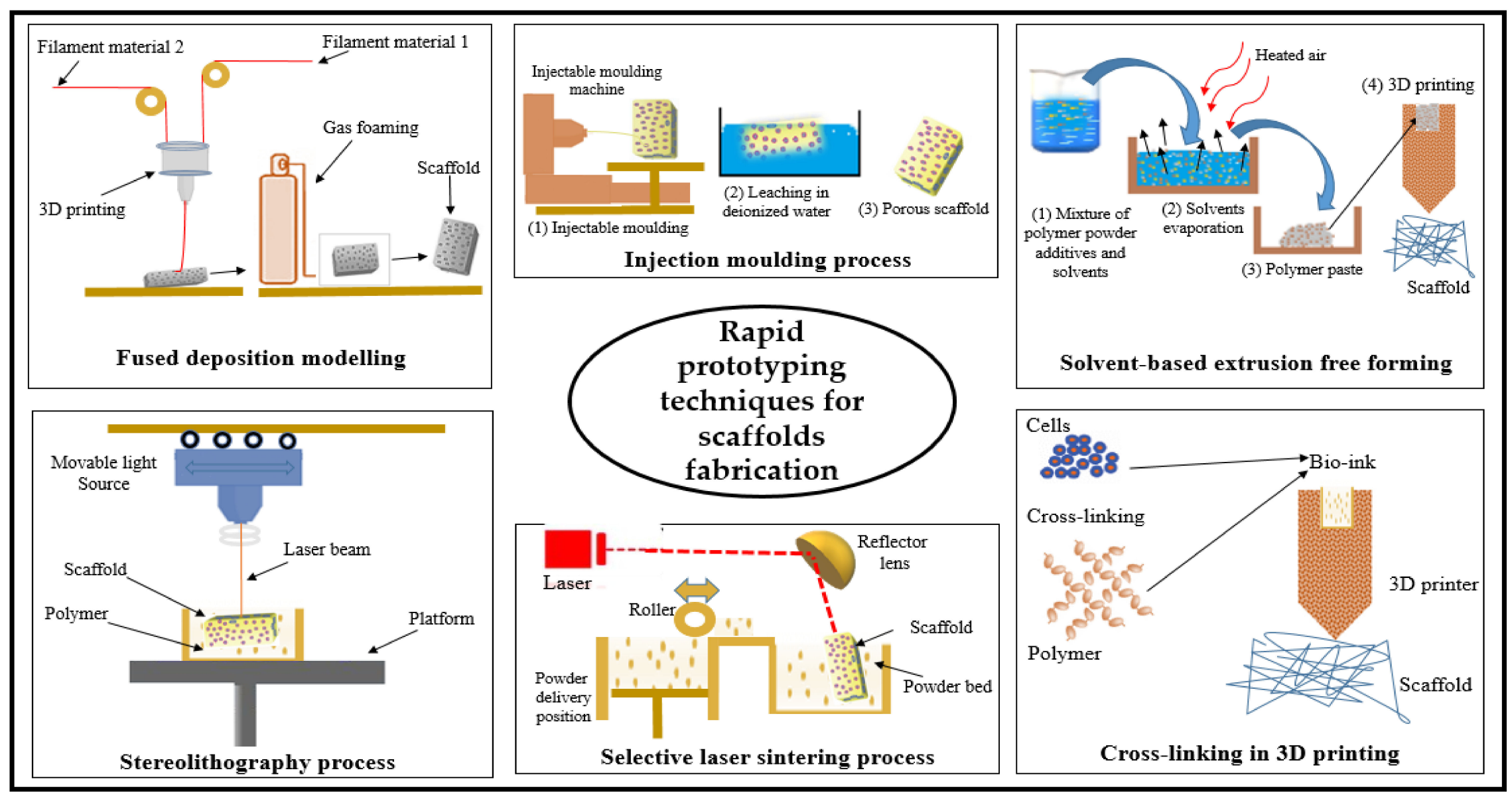

Figure 7. Schematic drawing of biopolymer forming rapid prototyping techniques for scaffolds. 


\subsection{Properties of Micro- and Nanocellulose-Based Blend Scaffolds}

Cellulosic material has good physiological inertness and biocompatibility, and these properties have attracted its use in tissue engineering [3]. Both micro- and nanocellulose materials have been used in the fabrication of scaffolds with various techniques, and this can be divided into three main aspects: (i) cellulose membrane scaffolds, (ii) cellulose matrix composite scaffolds, and (iii) surface modified scaffolds.

\subsubsection{Physical Properties}

The natural composition of cellulose-based materials has provided a suitable cell-friendly environment for growing cells in tissue engineering scaffolds and encourages cell attachment proliferation. Low cytotoxicity and high porosity of cellulose-based scaffolds have made these types of scaffolds the favourable choice for culturing a variety of cell types. ME Alemán-Domínguez et al. [129] prepared bio-scaffolds from a microcrystalline cellulose binary blend with the $3 \mathrm{D}$ printing technique to culture sheep bone marrow cells. It was reported that their scaffold had $450-500 \mu \mathrm{m}$ pore size and $50-60 \%$ porosity. The study also recorded a significant enhancement of cell proliferation. The researchers concluded that these materials had suitable properties for tissue engineering scaffolds. Salmoria et al. [126] used the selective laser sintering technique to fabricate starch-cellulose and cellulose-acetate scaffolds. The result revealed that specimens with smaller particle size had a higher degree of sintering, mechanical strength, and a significant level of closed pores. This was indicated by the density measurements and fractography analyses. Cellulose nanocrystals, on the other hand, had a significantly smaller size $(5-6 \mathrm{~nm})$ than microcrystalline cellulose $(20-24 \mu \mathrm{m})$ and starch. The cellulose nanocrystal based hydrogel scaffold by Yin et al. [157] showed a smaller pore diameter than the microcrystalline cellulose (about $80-120 \mu \mathrm{m}$ ). The authors reported that CNC significantly enhanced the physical property of the hydrogels, and played a vital role according to the rheology and swelling results. Similarly, He et al. [138] fabricated cellulose nanocrystals using the electrospinning technique. It was reported that the addition of CNC increased the tensile strength and elastic modulus. The thermal stability of the scaffold was also significantly improved. Other studies have concluded that using nanocellulose based scaffolds have better cell attachment due to the enhancement of physical and mechanical properties, which mainly affect the cell-scaffold interaction $[158,159]$. Novel polymer ternary blend scaffolds have been fabricated by Ninan et al. [160] to culture fibroblast cells. In their research, it was reported that the optimised ternary blend scaffold was highly porous (up to $88 \%$ ) and with significantly reduced pore sizes. The viability of cultured cells reported in the study was high. The ternary blend scaffold possessed high biocompatibility and low cytotoxicity. The attachment of cells to the scaffold surface has been an important feature of concern. However, cellulose-based materials tend to exhibit good cell attachment, which is enhanced by surface modifications to the scaffold. Further cell attachment properties have been undertaken with the addition of peptide coatings, protein, or plasma treatment [161].

\subsubsection{Mechanical Properties}

According to Pelling and Hickey [16], the mechanical properties of cellulose-based scaffolds depend mainly on its chemical structure, the crystal structure of the materials, and their degree of crystallisation. Ideally, tissue engineering scaffolds should have good mechanical properties in terms of the necessary strength to allow surgical handling in implantation. Atila et al. [162] used hydrophilic pullulan to enhance the mechanical strength of the cellulose-acetate scaffold. The addition of pullulan significantly increased fibre diameter, thickness, and porosity of the cellulose scaffold. Many materials have been produced with good mechanical properties, but due to the high porosity needed for in vitro, have failed when implanted due to insufficient capacity for vascularisation. The particle size of the precursor materials play a critical role in the mechanical properties of the prepared scaffold, and smaller particles size provide higher mechanical properties to the scaffold. Therefore, most current researchers 
have shown a preference for the use of nanocellulose for scaffolding [126]. The mechanical properties of cellulose-based scaffolds can be significantly enhanced with microspheres [163] as the microparticles improve the interconnectivity of the shaped pores. The improved connectivity leads to better nutrient supply and fluid exchange when the scaffold is in use. The microparticle sizes also have a significant impact on the mechanical properties of the formed scaffolds. Novel research, which would account for a balance between the mechanical properties and porous architecture sufficient to allow cell infiltration and vascularization, has not been fully explored.

\subsubsection{Biodegradability}

The lack of cellulose degradable enzymes such as cellulase make the material non-biodegradable in vivo. However, the form and chemical derivatisation of crystalline cellulose and blending of cellulose with other polymers or materials may affect its degree of degradation and even immune response. In vitro degradation of oxidised cellulose materials comprises two main phases. The first phase is the initial rapid degradation, which leads to the degradation of approximately $70-80 \%$ of the cellulose sample. The second phase has a slower degradation of an additional $5-10 \%$ of the sample. This leaves a small amount of non-resorbable cellulose-based material [164]. With periodate oxidation, many recent types of research have attempted to enhance the biodegradability in vitro [165]. Various micro-organisms use cellulose as a carbon source; hence, they degrade it with specific enzymes, but not on an in vivo scale.

Further experiments on in vivo degradation showed the marked degradation of oxidised cellulose membranes at all-time points, with the most rapid degradation over the first 2-4 weeks [164]. Natural or spontaneous biodegradation of cellulose chains leads to a slow breakdown of unaltered cellulose on the in vivo scale. In vivo, non-enzymatic degradation of cellulose has not been adequately studied yet [166].

\subsubsection{Biocompatibility and Cytotoxicity}

The term biocompatibility is described as the ability of a material to function in living tissue without complications. The biocompatibility of a material is often dependent on its cytotoxicity and the immunological response of that material on its exposure to the body fluids or cells [167]. A few pieces of research on the biocompatibility and cytotoxicity of the cellulose-based material have been conducted. Several studies have provided results on biocompatibility and cytotoxicity, but have not been fully explored due to a variety of cellulosic fibre sources, range of different methodologies, and sample preparations. A significant number of studies have confirmed that cellulose could be generally considered to be biocompatible with only moderate or no foreign body responses in vivo [168,169]. Ul-Islam et al. [158] analysed cell-scaffold interaction using a cancer cell line and cellulose/chitosan scaffolds. Strong adhesion and negligible aggregation of cancer cell lines were reported in the scaffold matrix and better cell-scaffold interaction than cell-cell interaction [158]. Ramphul et al. [170] reported that due to the presence of several $\mathrm{OH}$ groups, cellulose is more hydrophilic and hence will promote cellular interactions. The strong interaction between human cells and cellulose scaffolds have been linked with the downregulation of Notch receptors in the growing cells due to direct interaction between the strange material and the cells. Real-time polymerase chain reaction (RT-PCR) has been used to verify this hypothesis. Primers for notch -1 to 4 receptors have been used and revealed that the cell signalling pathway is responsible for the generation of the expected strong connection of cell lines with the scaffold and a weak connection among the cell lines themselves [158]. According to a study conducted, the interaction of NFC with the cells led to a high level of secreting inflammatory cytokine tumour necrosis factor-alpha (TNF- $\alpha$ ), which could be the result of fibre-receptor interactions, which are highly dependent on the surface chemistry of the material [159]. The secretion of TNF- $\alpha$ could be inhibited by the introduction of surface charges on the surface of cellulose scaffolds, which have been done by the same authors [159]. Other studies have suggested that the human body can fully degrade cellulose with cellulolytic enzymes, which would have inevitably caused some incompatibility [171]. 
The toxicology of cellulose-based materials used in tissue engineering has been conducted on the viability, proliferation of cells, and cytotoxicity. Table 8 shows a summary of some recent research into the toxicology of cellulose-based materials. Generally, there has been no evidence for serious impact or damage of cellulose-based materials at both the cellular and genetic level as well as in vivo organ and animal experiments. However, the inhalation of intake of a high percentage of nanocellulose may induce pulmonary inflammation due to the easy self-aggregation and non-degradation of nanocellulose in the body of animals.

Table 8. Research summary of toxicology analysis of micro- and nanocellulose-based materials.

\begin{tabular}{|c|c|c|c|}
\hline Material & Experiment & Conclusion & Reference \\
\hline $\begin{array}{l}\text { Microcrystalline Cellulose } \\
\text { (MCC) }\end{array}$ & $\begin{array}{c}\text { Cytotoxicity and viability } \\
\text { evaluation. }\end{array}$ & $\begin{array}{l}\text { No sign for cytotoxicity was } \\
\text { observed. }\end{array}$ & [172] \\
\hline $\begin{array}{l}\text { micro fibrillated cellulose } \\
\text { (NFC) }\end{array}$ & $\begin{array}{l}\text { Viability and cytokine of mouse } \\
\text { and human cells }\end{array}$ & $\begin{array}{l}\text { Not cytotoxic and does not cause } \\
\text { any effects to the cells. }\end{array}$ & [173] \\
\hline $\begin{array}{l}\text { MFC/ collagen-hydroxyapatite } \\
\text { (Col/HA) composite }\end{array}$ & $\begin{array}{l}\text { Viability and proliferation } \\
\text { of cells with MTT assay }\end{array}$ & $\begin{array}{l}\text { The composite has been not } \\
\text { cytotoxic, biocompatible and safe } \\
\text { to cells. }\end{array}$ & [174] \\
\hline Microcrystalline cellulose & Haemolytic assay & No cytotoxicity was observed. & [175] \\
\hline $\begin{array}{c}\text { Microcrystalline } \\
\text { cellulose/chitosan composite }\end{array}$ & $\begin{array}{l}\text { Cytotoxicity, Thrombogenesis, } \\
\text { and haemolytic evaluation. }\end{array}$ & $\begin{array}{l}\text { The composite showed neither } \\
\text { cytotoxicity nor thrombogenicity. }\end{array}$ & [176] \\
\hline Cellulose-based particles & $\begin{array}{l}\text { Viability of the probiotic bacteria } \\
\text { assessment. }\end{array}$ & $\begin{array}{l}\text { Generally presented a low toxicity } \\
\text { profile to the cell line. }\end{array}$ & [177] \\
\hline Cellulose nanofibres & $\begin{array}{l}\text { Eco-toxicological and feeding } \\
\text { experiments to Daphnia Magna. }\end{array}$ & $\begin{array}{l}\text { Low toxic potential to } \\
\text { filter-feeding organisms and low } \\
\text { expected environmental risks. }\end{array}$ & [178] \\
\hline Cellulose nanofibres & $\begin{array}{l}\text { Cytotoxicity, skin, and eye } \\
\text { irritation tests. }\end{array}$ & $\begin{array}{l}\text { Significantly induced cytotoxicity } \\
\text { But not induce skin and eye } \\
\text { irritation on 3D models. }\end{array}$ & [179] \\
\hline Cellulose nanofibrils & $\begin{array}{l}\text { Cytotoxicity and viability of } \\
\text { fibroblast cells }\end{array}$ & $\begin{array}{l}\text { No, exert acute toxic phenomena } \\
\text { on the cells was observed. }\end{array}$ & [180] \\
\hline Cellulose nanocrystals & $\begin{array}{l}\text { Cytotoxicity and viability } \\
\text { evaluation. }\end{array}$ & $\begin{array}{l}\text { No sign for cytotoxicity was } \\
\text { observed. }\end{array}$ & [181] \\
\hline $\begin{array}{l}\text { Cellulose nanocrystal/silver } \\
\text { nanorod }\end{array}$ & $\begin{array}{l}\text { In vitro cytotoxicity of against } \\
\text { multiple eukaryotic cells. }\end{array}$ & $\begin{array}{c}\text { No effect on eukaryotic cells was } \\
\text { observed. }\end{array}$ & [182] \\
\hline Cellulose nanocrystals & $\begin{array}{l}\text { Cytotoxicity and viability with } \\
\text { the MTT assay. }\end{array}$ & $\begin{array}{l}\text { Cell viability slightly decreased } \\
\text { with increasing in CNC } \\
\text { concentration }\end{array}$ & [183] \\
\hline
\end{tabular}

\subsection{Classification of Micro/Nanocellulose-Based Scaffolds}

Over the past decade, several micro- and nanocellulose-based materials have been extensively studied and investigated as biomedical materials for various applications including scaffold fabrication for tissue engineering. However, an ideal tissue engineering scaffold possesses many other properties apart from the biocompatibility to evade adverse tissue reactions. Additionally, excellent mechanical properties and an interconnected porous structure are needed with retained hollow spaces to proliferate the growing cells. A significant number of studies have recently proven that cellulose-based material scaffolds with both micro- and nanoscale structures are suitable for tissue engineering $[30,184,185]$. Cellulose-based biomaterials offer some important advantages over conventional synthetic materials and show great promise to advance the frontier of scientific knowledge. Physical mixtures of two or more polymers, referred to as polymer blends that could be the same polymer (homo-polymers) or different polymers (copolymers), have been of great technological significance [186]. Cellulose-based blends have been extensively investigated because of their theoretical and practical importance, particularly in scaffold fabrication. 


\subsubsection{Micro- and Nanocellulose-Based Binary Blends Scaffold}

Polymer binary-blends have been described as materials composed of two individual polymers to produce an optimised one for the target application. Cellulose binary blends offer the potential to combine the unique properties of cellulose with other polymers with desirable properties in tissue-engineering scaffolding. Cellulose and chitosan have been proposed as promising systems for creating new materials such as fibres, blended films, and sponges. However, the two polymers in the binary-blends must form inter- and intra-molecular interaction between their macromolecules, which is referred to as the compatibility of the polymers [187]. The similarity in the chemical structures of the polymers can be used to predict their compatibility. Polymers with similar chemical structures are likely to be compatible (homogenous) with each other and vice versa [72]. Binary-blends of materials could be obtained from either solid (under high pressure and shear deformation) or liquid states [188]. The fabrication process of these materials is done by the dissolution of the desired two polymers separately in the same common solvent, or by blending the solid powder of the polymers and then simultaneously dissolving both polymers in the solvent.

\subsubsection{Micro- and Nanocellulose-Based Ternary Blends Scaffold}

The main purpose of blending the polymers is to obtain materials with additional properties with a minimum sacrifice of their original properties. The blending of three materials is referred to as ternary blends and have been a well-established route to achieving a certain number of physical polymer systems. It is often more rapid and economical than the development of new materials $[189,190]$. Ternary blends of micro- and nanocellulose-based materials for scaffold preparation have been researched. The material blends' miscibility is often enhanced with a plasticiser, which is often organic. Ternary blend scaffold materials that are micro- to nanocellulose-based with polylactic acid, chitin, and starch are most common because of their compatibility with the human system [191]. These blends have been used for skin tissue repair. The blend ratio has been reported to have a significant effect on the morphology, surface area, crystallinity, thermal properties, miscibility, surface hydrophilicity, and cell culture. Furthermore, ternary blend scaffolds have also been fabricated for skin regeneration applications with gelatine, cellulose acetate, and elastin [192]. The use of micro- and nanocellulose in ternary or multicomponent biopolymer blends for scaffold fabrication has enhanced the functional properties of scaffolds.

\section{The New Role of Cellulose-Based Scaffolds Bioengineering}

Biopolymer-based materials have been increasingly in use for the production of medical devices, pharmaceutical products, and tissue engineering scaffolds [193]. The chemical and mechanical properties of cellulose-based scaffolds are resistant to chemical reactions and enhanced cell growth factors [194]. Several techniques have been developed to shape cellulose-based materials into complex frameworks and support it with many materials to enhance their properties. The enhancement of the properties in the cellulose-based scaffold is majorly due to the desired demands for the growth, proliferation, differentiation, and shaping of cells in the environment in vivo conditions [195]. Furthermore, scaffolds must play a major role in the 3D shaping of the growing cells, forming natural tissue and then a whole organ. 3D printing technology has allowed researchers to fabricate more complex structures from cellulose materials by integrating layer-by-layer slices of the designed and desired objects. This revolutionary technology has been used in the regeneration of many organs such as articular cartilages [196].

\subsection{Issues and Potential}

The use of nanoparticles has raised many concerns among researchers. F. Ghaemi et al. [197] evaluated the toxicity of NFC and concluded that lower cytotoxicity to cells might be gathered from the NFC in scaffolds. In contrast, Kim et al. [179], even though there was no irritation to the skin and 
eyes, reported significant cytotoxicity to skin cells. However, Roman [198] reviewed the literature on the cytotoxicity that may be gathered from cellulose-based materials where it was concluded that no toxicity was demonstrated upon dermal and oral administration. Although a huge number of studies has been done to fabricate different scaffolds with different techniques, several grey areas still exist. Novel research, which would account for a balance between the mechanical properties and porous architecture sufficient to allow cell infiltration and vascularization, have not been fully explored. Furthermore, research on the culturing of cells on scaffolds, the long-term toxicology, and potential mutagenesis have not been done. At present, the cytotoxicity tests reported are without its effect on the genetic properties of the cells. In vitro growth of a whole graft, organs have been yet another obstacle and some simple structured organs (ex, skin) have already been fabricated, but some of them possess inflammatory and allergic responses [199]. The use of cellulose-based materials (biopolymer) in scaffold fabrication has many advantages over synthetic polymer materials. Still, the long-term effects and potential health risks must be widely studied to avoid possible undesirable mutations. Several studies have provided results that have not been fully explored due to a variety of cellulosic fibre sources and the range of different methodologies for scaffold preparations. In vivo, non-enzymatic degradation of cellulose has not been adequately studied yet. Moreover, the innovation of new cellulose composite materials with micro- and nanoscale tissue engineering techniques has been one of the challenges (i.e., to create fully bio-mimetic artificial tissues). As the complexity of the application increases such as in highly dynamic tissues, an active remodelling of the scaffold design and fabrication would be required.

\subsection{Future Prospect and Applications of Micro- and Nanocellulose-Based Scaffold}

Cellulose-based scaffolds have been widely used in tissue engineering allocation because of their high ability to form a different three-dimensional porous structure that mimics biological tissue and has excellent mechanical properties [200]. Reports of scaffolds prepared from cellulose hydrogels [201] showed that injectable nanocellulose hydrogels have gained wide application due to their minimally invasive injection into the target sites and ability to match irregular defects. Xu et al. [202] utilised cellulose hydrogel as a template for a nerve regeneration study using polyaniline as the nerve guidance conduit. In vitro and in vivo studies were conducted using Sprague-Dawley rats, and the composite hydrogels exhibited good mechanical and biocompatibility properties. The biocompatibility of cellulose micro- and nano-structures and electrical conductivity of polyaniline induced the adhesion and allowed the extension of neurons. Further studies on this could result in the use of cellulose hydrogel in nerve regeneration. Recently, 3D printing technologies of cellulose-based hydrogels for the fabrication of 3D shapes has also received extensive interest in tissue engineering scaffolds [203]. Markstedt et al. [204] developed revolutionary biomimetic all-wood-based ink for the regeneration of human organs, which was formed from the crossing-link of a matrix reinforced by cellulose nanofibres. The ink used was the main material for the 3D printer, which had a high water content and is preferable in tissue engineering applications. Similarly, Wu et al. [205] used 3D printing technology to fabricate binary blending alginate/NCC hydrogel scaffolds to mimic the liver structure. The hydrogel scaffold had excellent mechanical properties where hepatoma and fibroblasts cells incorporated into the scaffold very well, and the cell mortality was minimal during printing [205]. Artificial skin from a cellulose-based material has been widely developed and become commercially available. It was reported that cellulose-based scaffolds support the adhesion and growth of dermal fibroblasts [206], and supported colonisation with fibroblasts to a lower extent than the adhesion, spread, and growth of keratinocytes [207]. Khan et al. [163] used confocal microscopy to study the penetration of keratinocytes into the scaffolds and reported that the penetration was up to $300 \mu \mathrm{m}$ in depth. The same author did in vivo wound healing and skin regeneration experiments in mice and revealed complete skin regeneration within only two weeks, with much higher wound closure efficacy than that of the control. Another study was done by Huang et al. [208] that aimed to regenerate skin using cellulose-based scaffolds and adipose-derived mesenchymal stem cells. The artificial skin exhibited extremely high biological activity, a strong 
induction of cell recruitment, migration, growth, and upregulation of gene expression of relevant factors, resulting in excellent wound healing characteristics. The cell-scaffold interaction promoted the proliferation of cells and enhanced cell viability. With 3D technology, chemically modified NFC has been used as a bio-ink for printing and modifying film surfaces as artificial skin [209]. Bone and cartilage tissue replacements have also been fabricated using cellulose scaffolds. Cecen et al. [210] evaluated the biocompatibility, mechanical properties, and the interaction between the cellulose-based scaffold and chondrocyte-like cells. The results of the histological evaluation showed that cells produced an extracellular matrix. The extracellular matrix can be observed with the growth of proteoglycan and types I-II collagens. This growth showed that cellulose-based material promotes the proliferation of cartilage cells. The reverse templating method has been one of the most used and reliable methods in bone regeneration applications, which allows for mathematically defined and control pore geometries of the scaffolds, where [211] used this method to create gyroidal cellulose scaffolds. However, the natural structure of bone tissue is a complex of highly porous multi-layer tissue. Therefore, to fabricate artificial similar bone tissue, the used materials and methods should create highly porous biomimetic materials [123]. Rodríguez et al. [123] used the laser ablation of cellulose acetate electrospun fibres method to create high porosity with extremely small size pores without affecting the surrounding material. The porous mineralised scaffolds significantly increased the attachment and density of bone cells (osteoblast) at the pore sites [123]. Cellulose-based aerogels have been proven to be a promising candidate in tissue scaffold preparation. The mechanical properties of aerogels in the fabrication of designed scaffold for specific tissues allow the target cells to proliferate accordingly. Cellulose/polypyrrole composite aerogels have been fabricated by Shi et al. [212] who evaluated their potential application in nerve regeneration. The aerogel enhanced the adhesion and proliferation of nerve cells (PC12 cells), which were attached and extended longer. The high porosity of the cellulose-based aerogel provides high oxygen permeability and accelerates the exchange of metabolic requirements, which has been necessary for the growth and proliferation of cells leading to enhanced cell activity, better adhesion and increased proliferation and number of cells [213]. Chemical modification to enhance the interaction of cells with scaffolds and integrin-based attachment has also been proposed [214,215]. Nicole Pircher et al. [216] fabricated biocompatible cellulose-based aerogels of dual-porosity. The aerogel scaffolds exhibited high porosity and excellent mechanical properties that enhanced the spread and proliferation of growing fibroblast cells. Li et al. [106] prepared various aerogels from pure cellulose nanocrystals with the direct ink write technique. The technique was used to control the 3D structures of the scaffolds and the inner pore architecture. 3D printing quality can even be improved by increasing the concentration of cellulose nanocrystals and the printing resolution [106]. Various researchers have focused in the past few years to the functional analysis of essential biomarkers and the use of different scaffolds includes cellulose based scaffolds to direct the development of engineered 3D tissue models and organoids. The labelling of nanocellulose with fluorescent probes is of great interest as bio-markers and in sensor applications. Navarro et al. [217] converted cellulose nanofibrils into fluorescently labelled probes, which proved to be viable biomarkers and allowed for fluorescence-based optical detection of CNF uptake and distribution in organisms such as crustaceans. Donnell et al. [218] used the cellulose-binding domain (CBD) for designing biosensor scaffolds. The authors aimed to use these scaffolds to measure $\mathrm{pH}$ and $\mathrm{Ca}^{+2}$ gradients using fluorescence intensity and lifetime imaging detection modes. The use of cellulose-based scaffolds in diagnostic and biosensing has recently gained more attention. Kim et al. [219] evaluated the potential use of a cellulose-based patch for non-invasive monitoring of interstitial fluid (ISF) glucose levels. The authors used electrospun cellulose/ $\beta$-cyclodextrin ( $\beta-C D)$, which immobilised the GOx enzyme that can detect the epidermal glucose level. Table 9 shows a summary of the micro- and nanocellulose-based scaffolds in medical applications. Due to the recent advances in tissue engineering, regeneration medicine, and material science, great progress has been done in the development of many fabrication techniques and real cellulose-based scaffolds. Further attention should be given to other applications such as injectable scaffold delivery systems, biosensors, and diagnostic chips. Currently, tissue engineering only plays 
a small role in biomedicine, providing skin grafts when required, supplementary bladders, or small arteries. The increase in the intensity of accidents and population call for more researches to develop the current and new fabrication techniques. Many organs have been successfully grown in labs, but the use of tissue engineering remains in its infancy and is extremely costly. It has been proposed that the advancement in material development will result in a reduction in the cost of artificial organ development. Cellulose based tissue-engineering scaffolds have been proposed to solve the challenge of availability and affordability of several medical issues. The optimal cell source, scaffold design, in vitro bioreactors, the use, and development of microfabrication technology to create vascularised tissues and organs are still being investigated.

Table 9. Summary of selected applications of micro- and nanocellulose-based scaffolds.

\begin{tabular}{|c|c|c|}
\hline Material & Application \& Advantages & Reference \\
\hline Collagen/oxidized MCC & $\begin{array}{l}\text { Microcellulose improved the haemostasis of the } \\
\text { scaffolds without affecting its cytotoxicity. }\end{array}$ & [220] \\
\hline MFC/gelatine nanocomposite films & $\begin{array}{l}\text { Improved strength and flexibility of the films, which } \\
\text { could be used in drug delivery. }\end{array}$ & [221] \\
\hline $\begin{array}{l}\text { Micro-Nano structures of } \\
\text { cellulose-collagen }\end{array}$ & $\begin{array}{l}\text { Significantly enhanced the uniform and distribution of } \\
\text { cells, with good mechanical properties, may serve as } \\
\text { an alternative material platform for bone regeneration. }\end{array}$ & [222] \\
\hline $\begin{array}{l}\text { MFC/carboxymethyl chitosan } \\
\text { hydrogel }\end{array}$ & $\begin{array}{c}\text { The strength, porosity and the work of fracture } \\
\text { increased, providing a promising platform for tissue } \\
\text { engineering scaffold. }\end{array}$ & [223] \\
\hline Alginate/CNF scaffold & $\begin{array}{l}\text { Use in tissue engineering. CNF enhances mechanical } \\
\text { properties and makes it possible to tailored porosity } \\
\text { and swelling behaviour. }\end{array}$ & [224] \\
\hline Collagen/CNF hydrogel scaffold & $\begin{array}{l}\text { The addition of CNF to collagen scaffold improved its } \\
\text { mechanical properties with no effect on cell viability. }\end{array}$ & [225] \\
\hline PLA/CNF composite membrane & $\begin{array}{c}\text { CNF improved the crystalline ability of the membrane, } \\
\text { thermal stability and mechanical properties. } \\
\text { Hydrophilicity was also increased. }\end{array}$ & [226] \\
\hline $\begin{array}{l}\text { NCC/gelatine/hyaluronic acid } \\
\text { composite hydrogel }\end{array}$ & $\begin{array}{l}\text { NCC enhanced rheology and swelling results and the } \\
\text { other properties. The cells attached, grew, and } \\
\text { proliferated better than the control, giving the } \\
\text { composite a great potential for the skin wound repair. }\end{array}$ & [157] \\
\hline $\begin{array}{l}\text { Double crosslinking CNF } \\
\text { hydrogel scaffolds }\end{array}$ & $\begin{array}{l}\text { Wound healing and tissue repair. Increase in the } \\
\text { rigidity of scaffold enhances cell proliferation. }\end{array}$ & [149] \\
\hline
\end{tabular}

\section{Conclusions}

This review critically analysed the fabrication techniques of micro- and nanocellulose-based scaffolds. Various techniques have been critically reviewed for the fabrication of novel micro- and nanocellulose-based scaffolds with a balance between the mechanical properties and porous architecture that is sufficient to allow cell infiltration and proliferation. The future of scaffold fabrication techniques seems to be in the direction of the rapid prototyping of complex tissue and organs. Based on this review, the cellulose-based scaffold materials developed thus far have 3D frameworks with a high water uptake, tuneable functionalities, physicochemical, and mechanical properties. In addition, it is sustainable and available at low costs. This outstanding set of favourable characteristics offers almost endless possibilities of its application in tissue engineering. The report in this study showed that micro- and nanocellulose-based binary and ternary blends could effectively function as tissue engineering scaffold materials in direct cellular repair and damaged tissue regeneration. However, more studies in grey areas such as toxicity, in vivo, and non-enzymatic degradation of cellulose are needed. Furthermore, scaffold network development of a cellulose-based scaffold using high tech 
rapid prototyping is needed for the fabrication accuracy of a complex-shaped scaffold. The increase in the number of accidents and population call for more research to improve and develop new fabrication techniques. This will meet the demand for the effective treatment of severely damaged tissues and the high expectation on the development of tissue engineering technology.

Author Contributions: Conceptualisation, H.P.S.A.K., E.B.Y., and F.J.; Methodology, H.P.S.A.K. and E.B.Y.; Software, N.G.O., M.A.; Validation, A.S.H., N.N.A.M., and A.S.A.; Formal analysis, A.B.S., U.S.U.K. and R.B.; Investigation, H.P.S.A.K., E.B.Y., and F.J.; Resources, A.S.H., N.N.A.M., and A.S.A.; Data. H.P.S.A.K. and E.B.Y.; Writing-original draft preparation H.P.S.A.K., E.B.Y., and F.J.; Writing—review and editing, H.P.S.A.K., E.B.Y., and N.G.O.; Supervision H.P.S.A.K. and F.J.; Funding acquisition, H.P.S.A.K. and F.J. All authors have read and agreed to the published version of the manuscript.

Funding: This work was financially supported by the Ministry of Higher Education, FRGS-MRSA 203.PTEKIND.6711837.

Acknowledgments: The authors would like to thank the collaboration between the Management Science University Medical Centre, Selangor, Malaysia; the Faculty of Medicine, Universitas Syiah Kuala, Aceh, Indonesia; the Reconstructive Science Unit, School of Medical Sciences, Kubang Kerian, Kelantan, Malaysia; Hospital USM, Kubang Kerian, Kelantan, Malaysia; the Nanotechnology Research Centre, Faculty of Science and Mathematics, UPSI, Tanjung Malim, Perak, Malaysia; and the Universiti Sains Malaysia, Penang, Malaysia that made this work possible.

Conflicts of Interest: The authors declare no conflict of interest.

\section{References}

1. Bajwa, D.S.; Rehovsky, C.; Shojaeiarani, J.; Stark, N.; Bajwa, S.; Dietenberger, M.A. Functionalized cellulose nanocrystals: A potential fire retardant for polymer composites. Polymers 2019, 11, 1361. [CrossRef] [PubMed]

2. Rasad, M.S.B.A.; Halim, A.S.; Hashim, K.; Rashid, A.H.A.; Yusof, N.; Shamsuddin, S. In vitro evaluation of novel chitosan derivatives sheet and paste cytocompatibility on human dermal fibroblasts. Carbohydr. Polym. 2010, 79, 1094-1100. [CrossRef]

3. Abdul Khalil, H.; Adnan, A.; Yahya, E.B.; Olaiya, N.; Safrida, S.; Hossain, M.; Balakrishnan, V.; Gopakumar, D.A.; Abdullah, C.; Oyekanmi, A. A Review on Plant Cellulose Nanofibre-Based Aerogels for Biomedical Applications. Polymers 2020, 12, 1759. [CrossRef] [PubMed]

4. Khalil, H.A.; Tye, Y.Y.; Leh, C.P.; Saurabh, C.; Ariffin, F.; Fizree, H.M.; Mohamed, A.; Suriani, A. Cellulose reinforced biodegradable polymer composite film for packaging applications. In Bionanocomposites for Packaging Applications; Springer: Cham, Switzerland, 2018; pp. 49-69.

5. Tamaddon, F.; Hosseinzadeh, S. Anionic micro-cellulose (AMC): Preparation, characterization, and application as a novel heterogeneous base catalyst. Cellulose 2018, 25, 5277-5287. [CrossRef]

6. Murphy, C.A.; Collins, M.N. Microcrystalline cellulose reinforced polylactic acid biocomposite filaments for 3D printing. Polym. Compos. 2018, 39, 1311-1320. [CrossRef]

7. Marcovich, N.E.; Auad, M.L.; Bellesi, N.E.; Nutt, S.R.; Aranguren, M.I. Cellulose micro/nanocrystals reinforced polyurethane. J. Mater. Res. 2006, 21, 870-881. [CrossRef]

8. Khalil, H.A.; Tye, Y.Y.; Chow, S.T.; Saurabh, C.K.; Paridah, M.T.; Dungani, R.; Syakir, M.I. Cellulosic pulp fiber as reinforcement materials in seaweed-based film. BioResources 2017, 12, 29-42.

9. Nosar, M.N.; Salehi, M.; Ghorbani, S.; Beiranvand, S.P.; Goodarzi, A.; Azami, M. Characterization of wet-electrospun cellulose acetate based 3-dimensional scaffolds for skin tissue engineering applications: Influence of cellulose acetate concentration. Cellulose 2016, 23, 3239-3248. [CrossRef]

10. Sultan, S.; Mathew, A.P. 3D Printed Porous Cellulose Nanocomposite Hydrogel Scaffolds. JoVE (J. Visual. Exp.) 2019, 146, e59401. [CrossRef]

11. Osorio, D.A.; Lee, B.E.; Kwiecien, J.M.; Wang, X.; Shahid, I.; Hurley, A.L.; Cranston, E.D.; Grandfield, K. Cross-linked cellulose nanocrystal aerogels as viable bone tissue scaffolds. Acta Biomater. 2019, 87, 152-165. [CrossRef]

12. Naeem, M.A.; Alfred, M.; Lv, P.; Zhou, H.; Wei, Q. Three-dimensional bacterial cellulose-electrospun membrane hybrid structures fabricated through in-situ self-assembly. Cellulose 2018, 25, 6823-6830. [CrossRef]

13. Chung, T.-S.; Jiang, L.Y.; Li, Y.; Kulprathipanja, S. Mixed matrix membranes (MMMs) comprising organic polymers with dispersed inorganic fillers for gas separation. Prog. Polym. Sci. 2007, 32, 483-507. [CrossRef] 
14. Athukoralalage, S.S.; Balu, R.; Dutta, N.K.; Roy Choudhury, N. 3D bioprinted nanocellulose-based hydrogels for tissue engineering applications: A brief review. Polymers 2019, 11, 898. [CrossRef] [PubMed]

15. Liu, W.; Du, H.; Zhang, M.; Liu, K.; Liu, H.; Xie, H.; Zhang, X.; Si, C. Bacterial Cellulose-Based Composite Scaffolds for Biomedical Applications: A Review. ACS Sustain. Chem. Eng. 2020, 8, 7536-7562. [CrossRef]

16. Hickey, R.J.; Pelling, A.E. Cellulose biomaterials for tissue engineering. Front. Bioeng. Biotechnol. $2019,7,45$. [CrossRef]

17. Czaja, W.K.; Young, D.J.; Kawecki, M.; Brown, R.M. The future prospects of microbial cellulose in biomedical applications. Biomacromolecules 2007, 8, 1-12. [CrossRef]

18. Picheth, G.F.; Pirich, C.L.; Sierakowski, M.R.; Woehl, M.A.; Sakakibara, C.N.; de Souza, C.F.; Martin, A.A.; da Silva, R.; de Freitas, R.A. Bacterial cellulose in biomedical applications: A review. Int. J. Biol. Macromol. 2017, 104, 97-106. [CrossRef]

19. Rajwade, J.; Paknikar, K.; Kumbhar, J. Applications of bacterial cellulose and its composites in biomedicine. Appl. Microbiol. Biotechnol. 2015, 99, 2491-2511. [CrossRef]

20. Bourmaud, A.; Beaugrand, J.; Shah, D.U.; Placet, V.; Baley, C. Towards the design of high-performance plant fibre composites. Prog. Mater. Sci. 2018, 97, 347-408. [CrossRef]

21. Zhong, Y.; Kureemun, U.; Tran, L.Q.N.; Lee, H.P. Natural plant fiber composites-constituent properties and challenges in numerical modeling and simulations. Int. J. Appl. Mech. 2017, 9, 1750045. [CrossRef]

22. Bourmaud, A.; Mayer-Laigle, C.; Baley, C.; Beaugrand, J. About the frontier between filling and reinforcement by fine flax particles in plant fibre composites. Ind. Crops Prod. 2019, 141, 111774. [CrossRef]

23. George, J.; Sabapathi, S. Cellulose nanocrystals: Synthesis, functional properties, and applications. Nanotechnol. Sci. Appl. 2015, 8, 45-54. [CrossRef]

24. Hurtado, P.L.; Rouilly, A.; Vandenbossche, V.; Raynaud, C. A review on the properties of cellulose fibre insulation. Build. Environ. 2016, 96, 170-177. [CrossRef]

25. Mahltig, B.; Günther, K.; Askani, A.; Bohnet, F.; Brinkert, N.; Kyosev, Y.; Weide, T.; Krieg, M.; Leisegang, T. $\mathrm{X}$-ray-protective organic/inorganic fiber-along the textile chain from fiber production to clothing application. J. Text. Inst. 2017, 108, 1975-1984. [CrossRef]

26. Hokkanen, S.; Bhatnagar, A.; Sillanpää, M. A review on modification methods to cellulose-based adsorbents to improve adsorption capacity. Water Res. 2016, 91, 156-173. [CrossRef]

27. Seabra, A.B.; Bernardes, J.S.; Fávaro, W.J.; Paula, A.J.; Durán, N. Cellulose nanocrystals as carriers in medicine and their toxicities: A review. Carbohydr. Polym. 2018, 181, 514-527. [CrossRef] [PubMed]

28. Madsen, B.; Gamstedt, E.K. Wood versus plant fibers: Similarities and differences in composite applications. Adv. Mater. Sci. Eng. 2013, 2013, 564346. [CrossRef]

29. Moon, R.J.; Martini, A.; Nairn, J.; Simonsen, J.; Youngblood, J. Cellulose nanomaterials review: Structure, properties and nanocomposites. Chem. Soc. Rev. 2011, 40, 3941-3994. [CrossRef]

30. Huang, Y.; Wang, J.; Yang, F.; Shao, Y.; Zhang, X.; Dai, K. Modification and evaluation of micro-nano structured porous bacterial cellulose scaffold for bone tissue engineering. Mater. Sci. Eng. C Mater. Biol. Appl. 2017, 75, 1034-1041. [CrossRef]

31. Pacheco, G.; de Mello, C.V.; Chiari-Andréo, B.G.; Isaac, V.L.B.; Ribeiro, S.J.L.; Pecoraro, É.; Trovatti, E. Bacterial cellulose skin masks_Properties and sensory tests. J. Cosm. Dermatol. 2018, 17, 840-847. [CrossRef]

32. Mishra, R.K.; Sabu, A.; Tiwari, S.K. Materials chemistry and the futurist eco-friendly applications of nanocellulose: Status and prospect. J. Saudi Chem. Soc. 2018, 22, 949-978. [CrossRef]

33. Klemm, D.; Heublein, B.; Fink, H.P.; Bohn, A. Cellulose: Fascinating biopolymer and sustainable raw material. Angew. Chem. Int. Ed. 2005, 44, 3358-3393. [CrossRef] [PubMed]

34. De Amorim, J.D.P.; de Souza, K.C.; Duarte, C.R.; da Silva Duarte, I.; Ribeiro, F.d.A.S.; Silva, G.S.; de Farias, P.M.A.; Stingl, A.; Costa, A.F.S.; Vinhas, G.M. Plant and bacterial nanocellulose: Production, properties and applications in medicine, food, cosmetics, electronics and engineering. A review. Environ. Chem. Lett. 2020, 18, 851-869. [CrossRef]

35. Jozala, A.F.; de Lencastre-Novaes, L.C.; Lopes, A.M.; de Carvalho Santos-Ebinuma, V.; Mazzola, P.G.; Pessoa, A., Jr.; Grotto, D.; Gerenutti, M.; Chaud, M.V. Bacterial nanocellulose production and application: A 10-year overview. Appl. Microbiol. Biotechnol. 2016, 100, 2063-2072. [CrossRef]

36. O'Connell, D.W.; Birkinshaw, C.; O'Dwyer, T.F. Heavy metal adsorbents prepared from the modification of cellulose: A review. Bioresour. Technol. 2008, 99, 6709-6724. [CrossRef] 
37. Borges, J.; Canejo, J.; Fernandes, S.; Brogueira, P.; Godinho, M. Cellulose-based liquid crystalline composite systems. Nanocell. Polym. Nanocompos. Fundam. Appl. Wiley Scrivener 2015, 215-235. [CrossRef]

38. Trache, D.; Hussin, M.H.; Chuin, C.T.H.; Sabar, S.; Fazita, M.N.; Taiwo, O.F.; Hassan, T.; Haafiz, M.M. Microcrystalline cellulose: Isolation, characterization and bio-composites application-A review. Int. J. Biol. Macromol. 2016, 93, 789-804. [CrossRef]

39. Sotnikova, Y.S.; Demina, T.; Istomin, A.; Goncharuk, G.; Grandfils, C.; Akopova, T.; Zelenetskii, A.; Babayevsky, P. Application of micro-and nanocrystalline cellulose. In Proceedings of the IOP Conference Series: Materials Science and Engineering, Moscow, Russia, 21-24 November 2017.

40. DeCampos, A.; Corrêa, A.C.; Claro, P.I.C.; de Morais Teixeira, E.; Marconcini, J.M. Processing, Characterization and Application of Micro and Nanocellulose Based Environmentally Friendly Polymer Composites. In Sustainable Polymer Composites and Nanocomposites; Springer: Cham, Switzerland, 2019; pp. 1-35.

41. Wang, T.; Hong, M. Solid-state NMR investigations of cellulose structure and interactions with matrix polysaccharides in plant primary cell walls. J. Exp. Bot. 2016, 67, 503-514. [CrossRef]

42. Sorieul, M.; Dickson, A.; Hill, S.J.; Pearson, H. Plant fibre: Molecular structure and biomechanical properties, of a complex living material, influencing its deconstruction towards a biobased composite. Materials 2016, 9, 618. [CrossRef]

43. Sreekumar, P.; Manirul Haque, S.; Afzal, H.M.; Sadique, Z.; Al-Harthi, M.A. Preparation and characterization of microcellulose reinforced polyvinyl alcohol/starch biocomposites. J. Compos. Mater. 2019, 53, 1933-1939. [CrossRef]

44. Oehme, D.P.; Doblin, M.S.; Wagner, J.; Bacic, A.; Downton, M.T.; Gidley, M.J. Gaining insight into cell wall cellulose macrofibril organisation by simulating microfibril adsorption. Cellulose 2015, 22, 3501-3520. [CrossRef]

45. Kataja, M.; Haavisto, S.; Salmela, J.; Lehto, R.; Koponen, A. Characterization of micro-fibrillated cellulose fiber suspension flow using multi scale velocity profile measurements. Nord. Pulp. Pap. Res. J. 2017, 32, 473-482. [CrossRef]

46. Saputro, A.; Verawati, I.; Ramahdita, G.; Chalid, M. Preparation of micro-fibrillated cellulose based on sugar palm ijuk (Arenga pinnata) fibres through partial acid hydrolysis. In Proceedings of the IOP Conference Series: Materials Science and Engineering, Medan, Indonesia, 7-10 November 2016; p. 012042.

47. Nie, K.; Song, Y.; Liu, S.; Han, G.; Ben, H.; Ragauskas, A.J.; Jiang, W. Preparation and Characterization of Microcellulose and Nanocellulose Fibers from Artemisia Vulgaris Bast. Polymers 2019, 11, 907. [CrossRef] [PubMed]

48. Akaraonye, E.; Filip, J.; Safarikova, M.; Salih, V.; Keshavarz, T.; Knowles, J.C.; Roy, I. Composite scaffolds for cartilage tissue engineering based on natural polymers of bacterial origin, thermoplastic poly (3-hydroxybutyrate) and micro-fibrillated bacterial cellulose. Polym. Int. 2016, 65, 780-791. [CrossRef]

49. Adel, A.M.; El-Gendy, A.A.; Diab, M.A.; Abou-Zeid, R.E.; El-Zawawy, W.K.; Dufresne, A. Microfibrillated cellulose from agricultural residues. Part I: Papermaking application. Ind. Crops Prod. 2016, 93, 161-174. [CrossRef]

50. El-Sakhawy, M.; Hassan, M.L. Physical and mechanical properties of microcrystalline cellulose prepared from agricultural residues. Carbohydr. Polym. 2007, 67, 1-10. [CrossRef]

51. Shi, S.; Zhang, M.; Zhang, S.; Hou, W.; Yan, Z. Evolution of Waster Cotton Fiber Hydro-Char Physicochemical Structure during Hydrothermal Carbonation. Preprints 2017, 2017, 110149. [CrossRef]

52. Ni, Z.-J.; Li, X.; Zhang, Y.-N.; Lou, B.-Y.; Pan, S.; Lv, Y.; Liu, D.-L. Micro-cellulose preparation method based on urea/naoh dissolved system. Univ. Politeh. Buchar. Sci. Bull. Ser. C Elect. Eng. Comput. Sci. 2017, 79, $45-54$.

53. Suryadi,H.; SUTRIYO, M.R.; LESTARI, Y.P.I. Potential of cellulase of Penicillium vermiculatum for preparation and characterization of microcrystalline cellulose produced from $\alpha$-cellulose of kapok pericarpium (ceiba pentandra). Int. J. Appl. Pharm. 2019, 11, 92-97. [CrossRef]

54. Hou, W.; Ling, C.; Shi, S.; Yan, Z. Preparation and characterization of microcrystalline cellulose from waste cotton fabrics by using phosphotungstic acid. Int. J. Biol. Macromol. 2019, 123, 363-368. [CrossRef]

55. Chaerunisaa, A.Y.; Sriwidodo, S.; Abdassah, M. Microcrystalline Cellulose as Pharmaceutical Excipient. In Pharmaceutical Formulation Design-Recent Practices; IntechOpen: London, UK, 2019.

56. Zugenmaier, P. Crystalline Cellulose and Derivatives: Characterization and Structures; Springer: Berlin/Heidelberg, Germany, 2008. 
57. Khalil, H.A.; Bhat, A.; Yusra, A.I. Green composites from sustainable cellulose nanofibrils: A review. Carbohydr. Polym. 2012, 87, 963-979. [CrossRef]

58. Ranby, B.G. Aqueous colloidal solutions of cellulose micelles. Acta Chem. Scand. 1949, 3, 649-650. [CrossRef]

59. Mokhena, T.C.; John, M.J. Cellulose nanomaterials: New generation materials for solving global issues. Cellulose 2020, 27, 1149-1194. [CrossRef]

60. Belali, N.G.; Chaerunisaa, A.Y.; Rusdiana, T. Isolation and Characterization of Microcrystalline Cellulose Derived from Plants as Excipient in Tablet: A Review. Indones. J. Pharm. 2019, 1, 55-61. [CrossRef]

61. Colvin, J.R.; Beer, M. The formation of cellulose microfibrils in suspensions of Acetobacter xylinum. Can. J. Microbiol. 1960, 6, 631-637. [CrossRef] [PubMed]

62. Halliwell, G. Hydrolysis of fibrous cotton and reprecipitated cellulose by cellulolytic enzymes from soil micro-organisms. Biochem. J. 1965, 95, 270-281. [CrossRef] [PubMed]

63. Heyn, A. The microcrystalline structure of cellulose in cell walls of cotton, ramie, and jute fibers as revealed by negative staining of sections. J. Cell Biol. 1966, 29, 181-197. [CrossRef]

64. Toshkov, T.S.; Gospodinov, N.R.; Vidimski, E.P. Method of Producing Microcrystalline Cellulose. U.S. Patent No. 3,954,727, 4 May 1976.

65. Kobayashi, S.; Kashiwa, K.; Shimada, J.; Kawasaki, T.; Shoda, S.i. Enzymatic polymerization: The first in vitro synthesis of cellulose via nonbiosynthetic path catalyzed by cellulase. Macromol. Symp. 1992, 54, 509-518. [CrossRef]

66. Revol, J.-F.; Godbout, L.; Gray, D. Solid self-assembled films of cellulose with chiral nematic order and optically variable properties. J. Pulp Paper Sci. 1998, 24, 146-149.

67. Nakagaito, A.; Yano, H. The effect of morphological changes from pulp fiber towards nano-scale fibrillated cellulose on the mechanical properties of high-strength plant fiber based composites. Appl. Phys. A 2004, 78, 547-552. [CrossRef]

68. Henriksson, M.; Henriksson, G.; Berglund, L.; Lindström, T. An environmentally friendly method for enzyme-assisted preparation of microfibrillated cellulose (MFC) nanofibers. Eur. Polym. J. 2007, 43, 3434-3441. [CrossRef]

69. Nyström, G.; Mihranyan, A.; Razaq, A.; Lindström, T.; Nyholm, L.; Strømme, M. A nanocellulose polypyrrole composite based on microfibrillated cellulose from wood. J. Phys. Chem. B 2010, 114, 4178-4182. [CrossRef] [PubMed]

70. Shao, Y.; Chaussy, D.; Grosseau, P.; Beneventi, D. Use of microfibrillated cellulose/lignosulfonate blends as carbon precursors: Impact of hydrogel rheology on 3D printing. Ind. Eng. Chem. Res. 2015, 54, 10575-10582. [CrossRef]

71. Alavi, M. Modifications of microcrystalline cellulose (MCC), nanofibrillated cellulose (NFC), and nanocrystalline cellulose (NCC) for antimicrobial and wound healing applications. e-Polymers 2019, 19, 103-119. [CrossRef]

72. Nuryawan, A.; Abdullah, C.; Hazwan, C.M.; Olaiya, N.; Yahya, E.B.; Risnasari, I.; Masruchin, N.; Baharudin, M.; Khalid, H.; Abdul Khalil, H. Enhancement of Oil Palm Waste Nanoparticles on the Properties and Characterization of Hybrid Plywood Biocomposites. Polymers 2020, 12, 1007. [CrossRef] [PubMed]

73. Kim, J.-H.; Shim, B.S.; Kim, H.S.; Lee, Y.-J.; Min, S.-K.; Jang, D.; Abas, Z.; Kim, J. Review of nanocellulose for sustainable future materials. Int. J. Prec. Eng. Manuf. Green Technol. 2015, 2, 197-213. [CrossRef]

74. Soyekwo, F.; Zhang, Q.; Gao, R.; Qu, Y.; Lin, C.; Huang, X.; Zhu, A.; Liu, Q. Cellulose nanofiber intermediary to fabricate highly-permeable ultrathin nanofiltration membranes for fast water purification. J. Membr. Sci. 2017, 524, 174-185. [CrossRef]

75. Lee, K.-Y. Nanocellulose and Sustainability: Production, Properties, Applications, and Case Studies; CRC Press: New York, NY, USA, 2018.

76. Okahisa, Y.; Furukawa, Y.; Ishimoto, K.; Narita, C.; Intharapichai, K.; Ohara, H. Comparison of cellulose nanofiber properties produced from different parts of the oil palm tree. Carbohydr. Polym. 2018, 198, 313-319. [CrossRef]

77. Doench, I.; Ahn Tran, T.; David, L.; Montembault, A.; Viguier, E.; Gorzelanny, C.; Sudre, G.; Cachon, T.; Louback-Mohamed, M.; Horbelt, N. Cellulose nanofiber-reinforced Chitosan hydrogel composites for intervertebral disc tissue repair. Biomimetics 2019, 4, 19. [CrossRef] 
78. Raza, Z.; Aslam, M.; Azeem, A.; Maqsood, H. Development and characterization of nano-crystalline cellulose incorporated poly (lactic acid) composite films. Mater. Werkst. 2019, 50, 64-73. [CrossRef]

79. Abraham, E.; Weber, D.E.; Sharon, S.; Lapidot, S.; Shoseyov, O. Multifunctional cellulosic scaffolds from modified cellulose nanocrystals. ACS Appl. Mater. Interfaces 2017, 9, 2010-2015. [CrossRef] [PubMed]

80. Lu, Y.; Yu, J.; Ma, J.; Wang, Z.; Fan, Y.; Zhou, X. High-yield preparation of cellulose nanofiber by small quantity acid assisted milling in glycerol. Cellulose 2019, 26, 3735-3745. [CrossRef]

81. Jiang, F.; Hsieh, Y.-L. Chemically and mechanically isolated nanocellulose and their self-assembled structures. Carbohydr. Polym. 2013, 95, 32-40. [CrossRef] [PubMed]

82. Ohkawa, K.; Hayashi, S.; Nishida, A.; Yamamoto, H.; Ducreux, J. Preparation of pure cellulose nanofiber via electrospinning. Text. Res. J. 2009, 79, 1396-1401. [CrossRef]

83. Shamskar, K.R.; Heidari, H.; Rashidi, A. Preparation and evaluation of nanocrystalline cellulose aerogels from raw cotton and cotton stalk. Ind. Crops Prod. 2016, 93, 203-211. [CrossRef]

84. Li, J.; Song, Z.; Li, D.; Shang, S.; Guo, Y. Cotton cellulose nanofiber-reinforced high density polyethylene composites prepared with two different pretreatment methods. Ind. Crops Prod. 2014, 59, 318-328. [CrossRef]

85. Chin, S.F.; Jimmy, F.B.; Pang, S.C. Size controlled fabrication of cellulose nanoparticles for drug delivery applications. J. Drug Deliv. Sci. Technol. 2018, 43, 262-266. [CrossRef]

86. Zhang, L.; Tsuzuki, T.; Wang, X. Preparation of cellulose nanofiber from softwood pulp by ball milling. Cellulose 2015, 22, 1729-1741. [CrossRef]

87. Li, W.; Yue, J.; Liu, S. Preparation of nanocrystalline cellulose via ultrasound and its reinforcement capability for poly (vinyl alcohol) composites. Ultrason. Sonochem. 2012, 19, 479-485. [CrossRef]

88. Cui, S.; Zhang, S.; Ge, S.; Xiong, L.; Sun, Q. Green preparation and characterization of size-controlled nanocrystalline cellulose via ultrasonic-assisted enzymatic hydrolysis. Ind. Crops Prod. 2016, 83, 346-352. [CrossRef]

89. Hietala, M.; Rollo, P.; Kekäläinen, K.; Oksman, K. Extrusion processing of green biocomposites: Compounding, fibrillation efficiency, and fiber dispersion. J. Appl. Polym. Sci. 2014, 131, 39981. [CrossRef]

90. Istomin, A.; Demina, T.; Subcheva, E.; Akopova, T.; Zelenetskii, A. Nanocrystalline cellulose from flax stalks: Preparation, structure, and use. Fibre Chem. 2016, 48, 199-201. [CrossRef]

91. Shaheen, T.I.; Montaser, A.; Li, S. Effect of cellulose nanocrystals on scaffolds comprising chitosan, alginate and hydroxyapatite for bone tissue engineering. Int. J. Biol. Macromol. 2019, 121, 814-821. [CrossRef] [PubMed]

92. Kim, H.J.; Oh, D.X.; Choy, S.; Nguyen, H.-L.; Cha, H.J.; Hwang, D.S. 3D cellulose nanofiber scaffold with homogeneous cell population and long-term proliferation. Cellulose 2018, 25, 7299-7314. [CrossRef]

93. Gu, H.; Gao, X.; Zhang, H.; Chen, K.; Peng, L. Fabrication and characterization of cellulose nanoparticles from maize stalk pith via ultrasonic-mediated cationic etherification. Ultrason. Sonochem. 2019, 66, 104932. [CrossRef]

94. Prud'homme, R.K.; Feng, J.; Ristroph, K.D.; LU, H.; Zhang, Y.; Mcmanus, S.A.; Pagels, R.F. Cellulosic Polymer Nanoparticles and Methods of Forming Them. US Patent App. 16/816,241, 2 July 2020.

95. Turbak, A.F.; Snyder, F.W.; Sandberg, K.R. Microfibrillated cellulose, a new cellulose product: Properties, uses, and commercial potential. J. Appl. Polym. Sci. Appl. Polym. Symp. 1983, 37. Available online: https://www.osti.gov/biblio/5062478-microfibrillated-cellulose-new-cellulose-product-propertiesuses-commercial-potential (accessed on 1 January 1983).

96. Azizi Samir, M.A.S.; Alloin, F.; Sanchez, J.-Y.; El Kissi, N.; Dufresne, A. Preparation of cellulose whiskers reinforced nanocomposites from an organic medium suspension. Macromolecules 2004, 37, 1386-1393. [CrossRef]

97. Svagan, A.J.; Azizi Samir, M.A.; Berglund, L.A. Biomimetic polysaccharide nanocomposites of high cellulose content and high toughness. Biomacromolecules 2007, 8, 2556-2563. [CrossRef]

98. Henriksson, M.; Berglund, L.A.; Isaksson, P.; Lindstrom, T.; Nishino, T. Cellulose nanopaper structures of high toughness. Biomacromolecules 2008, 9, 1579-1585. [CrossRef]

99. Fang, B.; Wan, Y.-Z.; Tang, T.-T.; Gao, C.; Dai, K.-R. Proliferation and osteoblastic differentiation of human bone marrow stromal cells on hydroxyapatite/bacterial cellulose nanocomposite scaffolds. Tissue Eng. Part A 2009, 15, 1091-1098. [CrossRef] 
100. Rosa, M.; Medeiros, E.; Malmonge, J.; Gregorski, K.; Wood, D.; Mattoso, L.; Glenn, G.; Orts, W.; Imam, S. Cellulose nanowhiskers from coconut husk fibers: Effect of preparation conditions on their thermal and morphological behavior. Carbohydr. Polym. 2010, 81, 83-92. [CrossRef]

101. Crotogino, R. NanoCellulose. In Proceedings of the International Symposium on Assessing the Economic Impact of Nanotechnology, Washington, DC, USA, 27-28 March 2012.

102. Dugan, J.M.; Gough, J.E.; Eichhorn, S.J. Bacterial cellulose scaffolds and cellulose nanowhiskers for tissue engineering. Nanomedicine 2013, 8, 287-298. [CrossRef]

103. Zhou, C.; Shi, Q.; Guo, W.; Terrell, L.; Qureshi, A.T.; Hayes, D.J.; Wu, Q. Electrospun bio-nanocomposite scaffolds for bone tissue engineering by cellulose nanocrystals reinforcing maleic anhydride grafted PLA. ACS Appl. Mater. Interfaces 2013, 5, 3847-3854. [CrossRef] [PubMed]

104. Yang, X.; Shi, K.; Zhitomirsky, I.; Cranston, E.D. Cellulose nanocrystal aerogels as universal 3D lightweight substrates for supercapacitor materials. Adv. Mater. 2015, 27, 6104-6109. [CrossRef]

105. Liu, J.; Cheng, F.; Grénman, H.; Spoljaric, S.; Seppälä, J.; Eriksson, J.E.; Willför, S.; Xu, C. Development of nanocellulose scaffolds with tunable structures to support 3D cell culture. Carbohydr. Polym. 2016, 148, 259-271. [CrossRef] [PubMed]

106. Li, V.C.-F.; Dunn, C.K.; Zhang, Z.; Deng, Y.; Qi, H.J. Direct ink write (DIW) 3D printed cellulose nanocrystal aerogel structures. Sci. Rep. 2017, 7, 1-8. [CrossRef] [PubMed]

107. Apelgren, P.; Karabulut, E.; Amoroso, M.; Mantas, A.; Martínez Ávila, H.c.; Kölby, L.; Kondo, T.; Toriz, G.; Gatenholm, P. In vivo human cartilage formation in three-dimensional bioprinted constructs with a novel bacterial nanocellulose bioink. ACS Biomater. Sci. Eng. 2019, 5, 2482-2490. [CrossRef]

108. Bukhari, N.; Joseph, J.P.; Hussain, J.; Adeeb, M.A.M.; Wakim, M.J.Y.; Yahya, E.B.; Arif, A.; Saleem, A.; Sharif, N. Prevalence of Human Papilloma Virus Sub Genotypes following Head and Neck Squamous Cell Carcinomas in Asian Continent, A Systematic Review Article. Asian Pac. J. Cancer Prev. APJCP 2019, 20, 3269-3277. [CrossRef]

109. Surya, I.; Olaiya, N.; Rizal, S.; Zein, I.; Sri Asprila, N.; Hasan, M.; Yahya, E.B.; Sadasivuni, K.; Abdul Khalil, H. Plasticizer Enhancement on the Miscibility and Thermomechanical Properties of Polylactic Acid-Chitin-Starch Composites. Polymers 2020, 12, 115. [CrossRef]

110. Stratton, S.; Shelke, N.B.; Hoshino, K.; Rudraiah, S.; Kumbar, S.G. Bioactive polymeric scaffolds for tissue engineering. Bioact. Mater. 2016, 1, 93-108. [CrossRef]

111. Gutiérrez-Hernández, J.M.; Escobar-García, D.M.; Escalante, A.; Flores, H.; González, F.J.; Gatenholm, P.; Toriz, G. In vitro evaluation of osteoblastic cells on bacterial cellulose modified with multi-walled carbon nanotubes as scaffold for bone regeneration. Mater. Sci. Eng. C 2017, 75, 445-453. [CrossRef] [PubMed]

112. Feiner, R.; Shapira, A.; Dvir, T. Scaffolds for tissue engineering of functional cardiac muscle. In Handbook of Tissue Engineering Scaffolds: Volume One; Elsevier: London, UK, 2019; pp. 685-703.

113. Bölgen, N. Electrospun materials for bone and tendon/ligament tissue engineering. In Electrospun Materials for Tissue Engineering and Biomedical Applications; Elsevier: London, UK, 2017; pp. 233-260.

114. Domingues, R.M.; Chiera, S.; Gershovich, P.; Motta, A.; Reis, R.L.; Gomes, M.E. Fabrication of anisotropically aligned nanofibrous scaffolds based on natural/synthetic polymer blends reinforced with cellulose nanocrystals for tendon tissue engineering. Front. Bioeng. Biotechnol. 2016, 4. [CrossRef]

115. Dhandayuthapani, B.; Yoshida, Y.; Maekawa, T.; Kumar, D.S. Polymeric scaffolds in tissue engineering application: A review. Int. J. Polym. Sci. 2011, 2011. [CrossRef]

116. Berthiaume, F.; Maguire, T.J.; Yarmush, M.L. Tissue engineering and regenerative medicine: History, progress, and challenges. Ann. Rev. Chem. Biomol. Eng. 2011, 2, 403-430. [CrossRef] [PubMed]

117. Olaiya, N.G.; Nuryawan, A.; Oke, P.K.; Abdul Khalil, H.; Rizal, S.; Mogaji, P.; Sadiku, E.; Suprakas, S.; Farayibi, P.K.; Ojijo, V. The role of two-step blending in the properties of starch/chitin/polylactic acid biodegradable composites for biomedical applications. Polymers 2020, 12, 592. [CrossRef] [PubMed]

118. Eltom, A.; Zhong, G.; Muhammad, A. Scaffold techniques and designs in tissue engineering functions and purposes: A review. Adv. Mater. Sci. Eng. 2019, 2019. [CrossRef]

119. Venkatesan, J.; Bhatnagar, I.; Kim, S.-K. Chitosan-alginate biocomposite containing fucoidan for bone tissue engineering. Mar. Drugs 2014, 12, 300-316. [CrossRef]

120. Teimouri, A.; Azadi, M.; Emadi, R.; Lari, J.; Chermahini, A.N. Preparation, characterization, degradation and biocompatibility of different silk fibroin based composite scaffolds prepared by freeze-drying method for tissue engineering application. Polym. Degrad. Stab. 2015, 121, 18-29. [CrossRef] 
121. Jafari, H.; Shahrousvand, M.; Kaffashi, B. Reinforced poly ( $\varepsilon$-caprolactone) bimodal foams via phospho-calcified cellulose nanowhisker for osteogenic differentiation of human mesenchymal stem cells. ACS Biomater. Sci. Eng. 2018, 4, 2484-2493. [CrossRef]

122. Annabi, N.; Fathi, A.; Mithieux, S.M.; Martens, P.; Weiss, A.S.; Dehghani, F. The effect of elastin on chondrocyte adhesion and proliferation on poly ( $\varepsilon$-caprolactone)/elastin composites. Biomaterials 2011, 32, 1517-1525. [CrossRef]

123. Rodríguez, K.; Sundberg, J.; Gatenholm, P.; Renneckar, S. Electrospun nanofibrous cellulose scaffolds with controlled microarchitecture. Carbohydr. Polym. 2014, 100, 143-149. [CrossRef]

124. Mi, H.-Y.; Jing, X.; Salick, M.R.; Cordie, T.M.; Turng, L.-S. Carbon nanotube (CNT) and nanofibrillated cellulose (NFC) reinforcement effect on thermoplastic polyurethane (TPU) scaffolds fabricated via phase separation using dimethyl sulfoxide (DMSO) as solvent. J. Mech. Behav. Biomed. Mater. 2016, 62, 417-427. [CrossRef]

125. Tang, A.; Li, J.; Li, J.; Zhao, S.; Liu, W.; Liu, T.; Wang, J.; Liu, Y. Nanocellulose/PEGDA aerogel scaffolds with tunable modulus prepared by stereolithography for three-dimensional cell culture. J. Biomater. Sci. Polym. Ed. 2019, 30, 797-814. [CrossRef]

126. Salmoria, G.V.; Klauss, P.; Paggi, R.A.; Kanis, L.A.; Lago, A. Structure and mechanical properties of cellulose based scaffolds fabricated by selective laser sintering. Polym. Test. 2009, 28, 648-652. [CrossRef]

127. Kolan, K.C.; Li, W.; Althage, R.; Semon, J.A.; Day, D.E.; Leu, M.C. Solvent and melt based extrusion 3D printing of polycaprolactone bioactive glass composite for tissue engineering. In Proceedings of the 3rd International Conference on Progress in Additive Manufacturing, Singapore, 14-17 May 2018.

128. Li, L.; Zhu, Y.; Yang, J. 3D bioprinting of cellulose with controlled porous structures from NMMO. Mater. Lett. 2018, 210, 136-138. [CrossRef]

129. Alemán-Domínguez, M.E.; Giusto, E.; Ortega, Z.; Tamaddon, M.; Benítez, A.N.; Liu, C. Three-dimensional printed polycaprolactone-microcrystalline cellulose scaffolds. J. Biomed. Mater. Res. Part B Appl. Biomater. 2019, 107, 521-528. [CrossRef]

130. Huang, A.; Jiang, Y.; Napiwocki, B.; Mi, H.; Peng, X.; Turng, L.-S. Fabrication of poly (e-caprolactone) tissue engineering scaffolds with fibrillated and interconnected pores utilizing microcellular injection molding and polymer leaching. RSC Adv. 2017, 7, 43432-43444. [CrossRef]

131. Kanimozhi, K.; Basha, S.K.; Kumari, V.S.; Kaviyarasu, K. Development of biomimetic hybrid porous scaffold of chitosan/polyvinyl alcohol/carboxymethyl cellulose by freeze-dried and salt leached technique. J. Nanosci. Nanotechnol. 2018, 18, 4916-4922. [CrossRef]

132. Chen, G.; Ushida, T.; Tateishi, T. Development of biodegradable porous scaffolds for tissue engineering. Mater. Sci. Eng. C 2001, 17, 63-69. [CrossRef]

133. Zubairi, S.I. Porous three dimensional (3-D) scaffolds of poly (3-hydroxybutyric acid)(PHB) and poly (3-hydroxybutyric-co-3-hydroxyvaleric acid)(PHBV): Determination of salt leaching efficiency of solvent-casting particulate-leaching (SCPL). Adv. Environ. Biol. 2014, 8, 925-932.

134. Khan, S.; Ul-Islam, M.; Ullah, M.W.; Ikram, M.; Subhan, F.; Kim, Y.; Jang, J.H.; Yoon, S.; Park, J.K. Engineered regenerated bacterial cellulose scaffolds for application in in vitro tissue regeneration. RSC Adv. 2015, 5, 84565-84573. [CrossRef]

135. Abdelaal, O.A.; Darwish, S.M. Review of rapid prototyping techniques for tissue engineering scaffolds fabrication. In Characterization and Development of Biosystems and Biomaterials; Springer: Berlin/Heidelberg, Germany, 2013; pp. 33-54.

136. Zhong, X.; Dehghani, F. Fabrication of biomimetic poly (propylene carbonate) scaffolds by using carbon dioxide as a solvent, monomer and foaming agent. Green Chem. 2012, 14, 2523-2533. [CrossRef]

137. Li, Z.; Xie, M.-B.; Li, Y.; Ma, Y.; Li, J.-S.; Dai, F.-Y. Recent progress in tissue engineering and regenerative medicine. J. Biomater. Tissue Eng. 2016, 6, 755-766. [CrossRef]

138. He, X.; Xiao, Q.; Lu, C.; Wang, Y.; Zhang, X.; Zhao, J.; Zhang, W.; Zhang, X.; Deng, Y. Uniaxially aligned electrospun all-cellulose nanocomposite nanofibers reinforced with cellulose nanocrystals: Scaffold for tissue engineering. Biomacromolecules 2014, 15, 618-627. [CrossRef]

139. Liu, C.; Xia, Z.; Czernuszka, J. Design and development of three-dimensional scaffolds for tissue engineering. Chem. Eng. Res. Des. 2007, 85, 1051-1064. [CrossRef]

140. Lu, T.; Li, Y.; Chen, T. Techniques for fabrication and construction of three-dimensional scaffolds for tissue engineering. Int. J. Nanomed. 2013, 8, 337-350. [CrossRef] 
141. Chia, H.N.; Wu, B.M. Recent advances in 3D printing of biomaterials. J. Biol. Eng. 2015, 9, 4. [CrossRef]

142. Rimell, J.T.; Marquis, P.M. Selective laser sintering of ultra high molecular weight polyethylene for clinical applications. J. Biomed. Mater. Res. Off. J. Soc. Biomater. Japn. Soc. Biomater. Aust. Soc. Biomater. Korean Soc. Biomater. 2000, 53, 414-420. [CrossRef]

143. Shuai, C.; Yuan, X.; Yang, W.; Peng, S.; He, C.; Feng, P.; Qi, F.; Wang, G. Cellulose nanocrystals as biobased nucleation agents in poly-l-lactide scaffold: Crystallization behavior and mechanical properties. Polym. Test. 2020, 85, 106458. [CrossRef]

144. Zhang, B.; Cristescu, R.; Chrisey, D.B.; Narayan, R.J. Solvent-based Extrusion 3D Printing for the Fabrication of Tissue Engineering Scaffolds. Int. J. Bioprinting 2020, 6, 211. [CrossRef]

145. Vaezi, M.; Yang, S. A novel bioactive PEEK/HA composite with controlled 3D interconnected HA network. Int. J. Bioprinting 2015, 1, 66-76. [CrossRef]

146. Lu, X.; Lee, Y.; Yang, S.; Hao, Y.; Evans, J.R.; Parini, C.G. Fine lattice structures fabricated by extrusion freeforming: Process variables. J. Mater. Proc. Technol. 2009, 209, 4654-4661. [CrossRef]

147. Wang, M.; Favi, P.; Cheng, X.; Golshan, N.H.; Ziemer, K.S.; Keidar, M.; Webster, T.J. Cold atmospheric plasma (CAP) surface nanomodified 3D printed polylactic acid (PLA) scaffolds for bone regeneration. Acta Biomater. 2016, 46, 256-265. [CrossRef]

148. Wu, Z.; Su, X.; Xu, Y.; Kong, B.; Sun, W.; Mi, S. Bioprinting three-dimensional cell-laden tissue constructs with controllable degradation. Sci. Rep. 2016, 6, 1-10. [CrossRef]

149. Xu, C.; Molino, B.Z.; Wang, X.; Cheng, F.; Xu, W.; Molino, P.; Bacher, M.; Su, D.; Rosenau, T.; Willför, S. 3D printing of nanocellulose hydrogel scaffolds with tunable mechanical strength towards wound healing application. J. Mater. Chem. B 2018, 6, 7066-7075. [CrossRef]

150. Murphy, S.V.; Atala, A. 3D bioprinting of tissues and organs. Nat. Biotechnol. 2014, 32, 773-785. [CrossRef]

151. Salgado, A.; Gomes, M.E.; Chou, A.; Coutinho, O.; Reis, R.; Hutmacher, D. Preliminary study on the adhesion and proliferation of human osteoblasts on starch-based scaffolds. Mater. Sci. Eng. C 2002, 20, 27-33. [CrossRef]

152. Banoriya, D.; Purohit, R.; Dwivedi, R. Modern trends in rapid prototyping for biomedical applications. Mater. Today Proc. 2015, 2, 3409-3418. [CrossRef]

153. Hoque, M.E.; Chuan, Y.L.; Pashby, I. Extrusion based rapid prototyping technique: An advanced platform for tissue engineering scaffold fabrication. Biopolymers 2012, 97, 83-93. [CrossRef]

154. Kim, G.H.; Ahn, S.H.; Lee, H.J.; Lee, S.; Cho, Y.; Chun, W. A new hybrid scaffold using rapid prototyping and electrohydrodynamic direct writing for bone tissue regeneration. J. Mater. Chem. 2011, 21, 19138-19143. [CrossRef]

155. Seunarine, K.; Gadegaard, N.; Tormen, M.; Meredith, D.; Riehle, M.; Wilkinson, C. 3D polymer scaffolds for tissue engineering. Fut. Med. 2006, 1, 281-296. [CrossRef] [PubMed]

156. Mondschein, R.J.; Kanitkar, A.; Williams, C.B.; Verbridge, S.S.; Long, T.E. Polymer structure-property requirements for stereolithographic 3D printing of soft tissue engineering scaffolds. Biomaterials 2017, 140, 170-188. [CrossRef] [PubMed]

157. Yin, F.; Lin, L.; Zhan, S. Preparation and properties of cellulose nanocrystals, gelatin, hyaluronic acid composite hydrogel as wound dressing. J. Biomater. Sci. Poly. Ed. 2019, 30, 190-201. [CrossRef] [PubMed]

158. Ul-Islam, M.; Subhan, F.; Islam, S.U.; Khan, S.; Shah, N.; Manan, S.; Ullah, M.W.; Yang, G. Development of three-dimensional bacterial cellulose/chitosan scaffolds: Analysis of cell-scaffold interaction for potential application in the diagnosis of ovarian cancer. Int. J. Biol. Macromol. 2019, 137, 1050-1059. [CrossRef] [PubMed]

159. Lopes, V.R.; Sanchez-Martinez, C.; Strømme, M.; Ferraz, N. In vitro biological responses to nanofibrillated cellulose by human dermal, lung and immune cells: Surface chemistry aspect. Part. Fibre Toxicol. 2017, $14,1$. [CrossRef] [PubMed]

160. Ninan, N.; Muthiah, M.; Park, I.-K.; Elain, A.; Thomas, S.; Grohens, Y. Pectin/carboxymethyl cellulose/microfibrillated cellulose composite scaffolds for tissue engineering. Carbohydr. Polym. 2013, 98, 877-885. [CrossRef]

161. Courtenay, J.C.; Johns, M.A.; Galembeck, F.; Deneke, C.; Lanzoni, E.M.; Costa, C.A.; Scott, J.L.; Sharma, R.I. Surface modified cellulose scaffolds for tissue engineering. Cellulose 2017, 24, 253-267. [CrossRef]

162. Atila, D.; Keskin, D.; Tezcaner, A. Cellulose acetate based 3-dimensional electrospun scaffolds for skin tissue engineering applications. Carbohydr. Polym. 2015, 133, 251-261. [CrossRef] 
163. Khan, S.; Ul-Islam, M.; Ikram, M.; Islam, S.U.; Ullah, M.W.; Israr, M.; Jang, J.H.; Yoon, S.; Park, J.K. Preparation and structural characterization of surface modified microporous bacterial cellulose scaffolds: A potential material for skin regeneration applications in vitro and in vivo. Int. J. Biol. Macromol. 2018, 117, 1200-1210. [CrossRef]

164. Czaja, W.; Kyryliouk, D.; DePaula, C.A.; Buechter, D.D. Oxidation of $\gamma$-irradiated microbial cellulose results in bioresorbable, highly conformable biomaterial. J. Appl. Polym. Sci. 2014, 131, 39995. [CrossRef]

165. Edlund, U.; Lagerberg, T.; Ålander, E. Admicellar polymerization coating of CNF enhances integration in degradable nanocomposites. Biomacromolecules 2018, 20, 684-692. [CrossRef]

166. Laurén, P. Biomedical Applications of Nanofibrillar Cellulose. Ph.D. Thesis, Helsinki University, Helsinki, Finland, 2018.

167. Von Recum, H.A. From Biocompatibility to Immune Engineering. Exp. Biol. Med. 2016, 241, 889. [CrossRef]

168. Togo, K.; Yamamoto, M.; Imai, M.; Akiyama, K.; Yamashita, A.C. Comparison of biocompatibility in cellulose triacetate dialysis membranes with homogeneous and asymmetric structures. Renal Replace. Ther. 2018, 4, 29. [CrossRef]

169. Strätz, J.; Liedmann, A.; Heinze, T.; Fischer, S.; Groth, T. Effect of Sulfation Route and Subsequent Oxidation on Derivatization Degree and Biocompatibility of Cellulose Sulfates. Macromol. Biosc. 2019, 20, 1900403. [CrossRef] [PubMed]

170. Ramphul, H.; Gimié, F.; Andries, J.; Jhurry, D.; Bhaw-Luximon, A. Sugar-cane bagasse cellulose-based scaffolds promote multi-cellular interactions, angiogenesis and reduce inflammation for skin tissue regeneration. Int. J. Biol. Macromol. 2020, 157, 296-310. [CrossRef] [PubMed]

171. Lin, N.; Dufresne, A. Nanocellulose in biomedicine: Current status and future prospect. Eur. Polym. J. 2014, 59, 302-325. [CrossRef]

172. Ali, A.A.A.R.; May, L.W.; Paterson, I.C.; John, J. OSC1: Assessment of Cytotoxicity of Microcrystalline Cellulose Reinforced Denture Base Resin. J. Indian Prosthodont. Soc. 2018, 18, S7. [CrossRef]

173. Vartiainen, J.; Pöhler, T.; Sirola, K.; Pylkkänen, L.; Alenius, H.; Hokkinen, J.; Tapper, U.; Lahtinen, P.; Kapanen, A.; Putkisto, K. Health and environmental safety aspects of friction grinding and spray drying of microfibrillated cellulose. Cellulose 2011, 18, 775-786. [CrossRef]

174. He, X.; Fan, X.; Feng, W.; Chen, Y.; Guo, T.; Wang, F.; Liu, J.; Tang, K. Incorporation of microfibrillated cellulose into collagen-hydroxyapatite scaffold for bone tissue engineering. Int. J. Biol. Macromol. 2018, 115, 385-392. [CrossRef]

175. Kalita, R.D.; Nath, Y.; Ochubiojo, M.E.; Buragohain, A.K. Extraction and characterization of microcrystalline cellulose from fodder grass; Setaria glauca (L) P. Beauv, and its potential as a drug delivery vehicle for isoniazid, a first line antituberculosis drug. Coll. Surf. B Biointerfaces 2013, 108, 85-89. [CrossRef]

176. Bajpai, S.; Chand, N.; Ahuja, S.; Roy, M. Vapor induced phase inversion technique to prepare chitosan/microcrystalline cellulose composite films: Synthesis, characterization and moisture absorption study. Cellulose 2015, 22, 3825-3837. [CrossRef]

177. Singh, P.; Medronho, B.; dos Santos, T.; Nunes-Correia, I.; Granja, P.; Miguel, M.G.; Lindman, B. On the viability, cytotoxicity and stability of probiotic bacteria entrapped in cellulose-based particles. Food Hydrocoll. 2018, 82, 457-465. [CrossRef]

178. Ogonowski, M.; Edlund, U.; Gorokhova, E.; Linde, M.; Ek, K.; Liewenborg, B.; Könnecke, O.; Navarro, J.R.; Breitholtz, M. Multi-level toxicity assessment of engineered cellulose nanofibrils in Daphnia magna. Nanotoxicology 2018, 12, 509-521. [CrossRef] [PubMed]

179. Kim, S.; Ji Gwak, E.; Jeong, S.; Lee, S.; Sim, W. Toxicity Evaluation of Cellulose Nanofibers (Cnfs) for Cosmetic Industry Application. J. Toxicol. Risk Assess 2019, 5, 29.

180. Alexandrescu, L.; Syverud, K.; Gatti, A.; Chinga-Carrasco, G. Cytotoxicity tests of cellulose nanofibril-based structures. Cellulose 2013, 20, 1765-1775. [CrossRef]

181. Coelho, C.C.; Michelin, M.; Cerqueira, M.A.; Gonçalves, C.; Tonon, R.V.; Pastrana, L.M.; Freitas-Silva, O.; Vicente, A.A.; Cabral, L.M.; Teixeira, J.A. Cellulose nanocrystals from grape pomace: Production, properties and cytotoxicity assessment. Carbohydr. Polym. 2018, 192, 327-336. [CrossRef]

182. Shaheen, T.I.; Fouda, A. Green approach for one-pot synthesis of silver nanorod using cellulose nanocrystal and their cytotoxicity and antibacterial assessment. Int. J. Biol. Macromol. 2018, 106, 784-792. [CrossRef] [PubMed] 
183. Xiao, Y.; Liu, Y.; Wang, X.; Li, M.; Lei, H.; Xu, H. Cellulose nanocrystals prepared from wheat bran: Characterization and cytotoxicity assessment. Int. J. Biol. Macromol. 2019, 140, 225-233. [CrossRef]

184. Nelson, C.; Khan, Y.; Laurencin, C.T. Nanofiber-microsphere (nano-micro) matrices for bone regenerative engineering: A convergence approach toward matrix design. Regen. Biomater. 2014, 1, 3-9. [CrossRef]

185. Lotfi, M.; Bagherzadeh, R.; Naderi-Meshkin, H.; Mahdipour, E.; Mafinezhad, A.; Sadeghnia, H.R.; Esmaily, H.; Maleki, M.; Hasssanzadeh, H.; Ghayaour-Mobarhan, M. Hybrid chitosan-\$-glycerol phosphate-gelatin nano-/micro fibrous scaffolds with suitable mechanical and biological properties for tissue engineering. Biopolymers 2016, 105, 163-175. [CrossRef]

186. La Mantia, F.; Morreale, M.; Botta, L.; Mistretta, M.; Ceraulo, M.; Scaffaro, R. Degradation of polymer blends: A brief review. Polym. Degrad. Stab. 2017, 145, 79-92. [CrossRef]

187. Kuzmina, O.; Heinze, T.; Wawro, D. Blending of cellulose and chitosan in alkyl imidazolium ionic liquids. ISRN Polym. Sci. 2012, 2012. [CrossRef]

188. Rogovina, S.Z.; Vikhoreva, G.A. Polysaccharide-based polymer blends: Methods of their production. Glycoconj. J. 2006, 23, 611. [CrossRef] [PubMed]

189. Ramasubramanian, S.; Nasreen, K.; Vijayalakshmi, K.; Govindarajan, C.; Sudha, P. Synthesis and Characterisation of Ternary Blends of Chitosan. Int. J. Chem. Res. 2011, 3, 27-32.

190. HPS, A.K.; Saurabh, C.K.; Adnan, A.; Fazita, M.N.; Syakir, M.; Davoudpour, Y.; Rafatullah, M.; Abdullah, C.; Haafiz, M.; Dungani, R. A review on chitosan-cellulose blends and nanocellulose reinforced chitosan biocomposites: Properties and their applications. Carbohydr. Polym. 2016, 150, 216-226.

191. Tuancharoensri, N.; Ross, G.M.; Mahasaranon, S.; Topham, P.D.; Ross, S. Ternary blend nanofibres of poly (lactic acid), polycaprolactone and cellulose acetate butyrate for skin tissue scaffolds: Influence of blend ratio and polycaprolactone molecular mass on miscibility, morphology, crystallinity and thermal properties. Polym. Int. 2017, 66, 1463-1472. [CrossRef]

192. Khalili, S.; Khorasani, S.N.; Razavi, S.M.; Hashemibeni, B.; Tamayol, A. Nanofibrous scaffolds with biomimetic composition for skin regeneration. Appl. Biochem. Biotechnol. 2019, 187, 1193-1203. [CrossRef]

193. Bajaj, P.; Schweller, R.M.; Khademhosseini, A.; West, J.L.; Bashir, R. 3D biofabrication strategies for tissue engineering and regenerative medicine. Ann. Rev. Biomed. Eng. 2014, 16, 247-276. [CrossRef]

194. Nada, A.A.; Arul, M.R.; Ramos, D.M.; Kroneková, Z.; Mosnáček, J.; Rudraiah, S.; Kumbar, S.G. Bioactive polymeric formulations for wound healing. Polym. Adv. Technol. 2018, 29, 1815-1825. [CrossRef]

195. Rusu, D.; Ciolacu, D.; Simionescu, B.C. Cellulose-based hydrogels in tissue engineering applications. Cell. Chem. Technol. 2019, 53, 907-923. [CrossRef]

196. Müller, M.; Öztürk, E.; Arlov, Ø.; Gatenholm, P.; Zenobi-Wong, M. Alginate sulfate-nanocellulose bioinks for cartilage bioprinting applications. Ann. Biomed. Eng. 2017, 45, 210-223. [CrossRef] [PubMed]

197. Ghaemi, F.; Abdullah, L.C. Comparative study of cytotoxicity effect between cellulose nanocrystal and cellulose nanofiber. Adv. Nanobiotechnol. 2018, 1, 1-3.

198. Roman, M. Toxicity of cellulose nanocrystals: A review. Ind. Biotechnol. 2015, 11, 25-33. [CrossRef]

199. Blackstone, B.N.; Hahn, J.M.; McFarland, K.L.; DeBruler, D.M.; Supp, D.M.; Powell, H.M. Inflammatory response and biomechanical properties of coaxial scaffolds for engineered skin in vitro and post-grafting. Acta Biomater. 2018, 80, 247-257. [CrossRef] [PubMed]

200. Domingues, R.M.; Gomes, M.E.; Reis, R.L. The potential of cellulose nanocrystals in tissue engineering strategies. Biomacromolecules 2014, 15, 2327-2346. [CrossRef]

201. Sivashanmugam, A.; Kumar, R.A.; Priya, M.V.; Nair, S.V.; Jayakumar, R. An overview of injectable polymeric hydrogels for tissue engineering. Eur. Polym. J. 2015, 72, 543-565. [CrossRef]

202. Xu, D.; Fan, L.; Gao, L.; Xiong, Y.; Wang, Y.; Ye, Q.; Yu, A.; Dai, H.; Yin, Y.; Cai, J. Micro-nanostructured polyaniline assembled in cellulose matrix via interfacial polymerization for applications in nerve regeneration. ACS Appl. Mater. Interfaces 2016, 8, 17090-17097. [CrossRef]

203. Piras, C.C.; Fernández-Prieto, S.; De Borggraeve, W.M. Nanocellulosic materials as bioinks for 3D bioprinting. Biomater. Sci. 2017, 5, 1988-1992. [CrossRef]

204. Markstedt, K.; Escalante, A.; Toriz, G.; Gatenholm, P. Biomimetic inks based on cellulose nanofibrils and cross-linkable xylans for 3D printing. ACS Appl. Mater. Interfaces 2017, 9, 40878-40886. [CrossRef]

205. Wu, Y.; Lin, Z.Y.W.; Wenger, A.C.; Tam, K.C.; Tang, X.S. 3D bioprinting of liver-mimetic construct with alginate/cellulose nanocrystal hybrid bioink. Bioprinting 2018, 9, 1-6. [CrossRef] 
206. Johnen, C.; Steffen, I.; Beichelt, D.; Bräutigam, K.; Witascheck, T.; Toman, N.; Moser, V.; Ottomann, C.; Hartmann, B.; Gerlach, J. Culture of subconfluent human fibroblasts and keratinocytes using biodegradable transfer membranes. Burns 2008, 34, 655-663. [CrossRef]

207. Sanchavanakit, N.; Sangrungraungroj, W.; Kaomongkolgit, R.; Banaprasert, T.; Pavasant, P.; Phisalaphong, M. Growth of human keratinocytes and fibroblasts on bacterial cellulose film. Biotechnol. Prog. 2006, 22, 1194-1199. [CrossRef] [PubMed]

208. Huang, R.; Wang, J.; Chen, H.; Shi, X.; Wang, X.; Zhu, Y.; Tan, Z. The topography of fibrous scaffolds modulates the paracrine function of Ad-MSCs in the regeneration of skin tissues. Biomater. Sci. 2019, 7, 4248-4259. [CrossRef] [PubMed]

209. Rees, A.; Powell, L.C.; Chinga-Carrasco, G.; Gethin, D.T.; Syverud, K.; Hill, K.E.; Thomas, D.W. 3D bioprinting of carboxymethylated-periodate oxidized nanocellulose constructs for wound dressing applications. BioMed Res. Int. 2015, 2015, 925757. [CrossRef]

210. Cecen, B.; Kozaci, L.D.; Yuksel, M.; Ustun, O.; Ergur, B.U.; Havitcioglu, H. Biocompatibility and biomechanical characteristics of loofah based scaffolds combined with hydroxyapatite, cellulose, poly-l-lactic acid with chondrocyte-like cells. Mater. Sci. Eng. C 2016, 69, 437-446. [CrossRef] [PubMed]

211. Torres-Rendon, J.G.; Femmer, T.; De Laporte, L.; Tigges, T.; Rahimi, K.; Gremse, F.; Zafarnia, S.; Lederle, W.; Ifuku, S.; Wessling, M. Bioactive gyroid scaffolds formed by sacrificial templating of nanocellulose and nanochitin hydrogels as instructive platforms for biomimetic tissue engineering. Adv. Mater. 2015, 27, 2989-2995. [CrossRef]

212. Shi, Z.; Gao, H.; Feng, J.; Ding, B.; Cao, X.; Kuga, S.; Wang, Y.; Zhang, L.; Cai, J. In situ synthesis of robust conductive cellulose/polypyrrole composite aerogels and their potential application in nerve regeneration. Angew. Chem. Int. Ed. 2014, 53, 5380-5384. [CrossRef]

213. Sun, D.; Liu, W.; Tang, A.; Guo, F.; Xie, W. A new PEGDA/CNF aerogel-wet hydrogel scaffold fabricated by a two-step method. Soft Matter 2019, 15, 8092-8101. [CrossRef]

214. Innala, M.; Riebe, I.; Kuzmenko, V.; Sundberg, J.; Gatenholm, P.; Hanse, E.; Johannesson, S. 3D Culturing and differentiation of SH-SY5Y neuroblastoma cells on bacterial nanocellulose scaffolds. Artif. Cells Nanomed. Biotechnol. 2014, 42, 302-308. [CrossRef]

215. Jonsson, M.; Brackmann, C.; Puchades, M.; Brattås, K.; Ewing, A.; Gatenholm, P.; Enejder, A. Neuronal networks on nanocellulose scaffolds. Tissue Eng. Part C Methods 2015, 21, 1162-1170. [CrossRef]

216. Pircher, N.; Fischhuber, D.; Carbajal, L.; Strauß, C.; Nedelec, J.M.; Kasper, C.; Rosenau, T.; Liebner, F. Preparation and reinforcement of dual-porous biocompatible cellulose scaffolds for tissue engineering. Macromol. Mater. Eng. 2015, 300, 911-924. [CrossRef] [PubMed]

217. Navarro, J.R.; Wennmalm, S.; Godfrey, J.; Breitholtz, M.; Edlund, U. Luminescent nanocellulose platform: From controlled graft block copolymerization to biomarker sensing. Biomacromolecules 2016, 17, 1101-1109. [CrossRef] [PubMed]

218. O'Donnell, N.; Okkelman, I.A.; Timashev, P.; Gromovykh, T.I.; Papkovsky, D.B.; Dmitriev, R.I. Cellulose-based scaffolds for fluorescence lifetime imaging-assisted tissue engineering. Acta Biomater. 2018, 80, 85-96. [CrossRef]

219. Kim, K.O.; Kim, G.J.; Kim, J.H. A cellulose/ $\beta$-cyclodextrin nanofiber patch as a wearable epidermal glucose sensor. RSC Adv. 2019, 9, 22790-22794. [CrossRef]

220. Li, H.; Cheng, W.; Liu, K.; Chen, L.; Huang, Y.; Wang, X.; Lv, Z.; He, J.; Li, C. Reinforced collagen with oxidized microcrystalline cellulose shows improved hemostatic effects. Carbohydr. Polym. 2017, 165, 30-38. [CrossRef]

221. Quero, F.; Padilla, C.; Campos, V.; Luengo, J.; Caballero, L.; Melo, F.; Li, Q.; Eichhorn, S.J.; Enrione, J. Stress transfer and matrix-cohesive fracture mechanism in microfibrillated cellulose-gelatin nanocomposite films. Carbohydr. Polym. 2018, 195, 89-98. [CrossRef]

222. Aravamudhan, A.; Ramos, D.M.; Nip, J.; Kalajzic, I.; Kumbar, S.G. Micro-nanostructures of cellulose-collagen for critical sized bone defect healing. Macromol. Biosci. 2018, 18, 1700263. [CrossRef]

223. Wei, D.; Liu, Q.; Liu, Z.; Liu, J.; Zheng, X.; Pei, Y.; Tang, K. Modified nano microfibrillated cellulose/carboxymethyl chitosan composite hydrogel with giant network structure and quick gelation formability. Int. J. Biol. Macromol. 2019, 135, 561-568. [CrossRef]

224. Zhang, Y.; Wang, C.; Liu, Y.; Jiang, W.; Han, G. Preparation and characterization of composite scaffold of alginate and cellulose nanofiber from ramie. Text. Res. J. 2019, 89, 3260-3268. [CrossRef] 
225. Lohrasbi, S.; Mirzaei, E.; Karimizade, A.; Takallu, S.; Rezaei, A. Collagen/cellulose nanofiber hydrogel scaffold: Physical, mechanical and cell biocompatibility properties. Cellulose 2020, 27, 927-940. [CrossRef]

226. Yang, Z.; Li, X.; Si, J.; Cui, Z.; Peng, K. Morphological, mechanical and thermal properties of poly (lactic acid)(PLA)/cellulose nanofibrils (CNF) composites nanofiber for tissue engineering. J. Wuhan Univ. Technol. Mater. Sci. Ed. 2019, 34, 207-215. [CrossRef] 